\title{
NOTES
}

\section{FEDERAL JUDICIAL REVIEW OF STATE WELFARE PRACTICES}

No group is more dependent upon public largesse than the recipients of welfare payments. Indeed, the everyday actions of the governmental bureaucracy are, for them, virtual conditions of survival. Despite the preeminent role which administrative decisions play in the lives of these individuals, their interests have not, until recently, been given voice. However, an emerging, militant leadership is revealing to the nation the lawlessness which often characterizes the administration of welfare programs. A major goal of this movement has been to secure federal judicial review of the various types of decisions made in the administration of federally supported, state welfare programs. The path to the federal courts is, however, strewn with a number of potential obstructions. It is the purpose of this Note to examine the various procedural obstacles confronting the welfare claimant and to reveal the ways in which they may be overcome.

\section{The Structure of the Welfare Programs}

Public welfare in the United States takes the forms of general assistance and categorical assistance. ${ }^{1}$ General assistance is financed by local and state governments. ${ }^{2}$ Although programs of this sort provided the only public aid available prior to the Depression, they now furnish only a small portion of public welfare funds. ${ }^{3}$ Categorical assistance is today the predominant form of public welfare. Under this scheme, state programs which are supported by grants-in-aid from the federal government pursuant to the Social Security Act administer aid to specific categories of needy individuals and families. ${ }^{4}$ The federal statute recognizes four major categories: Old Age Assistance (OAA), ${ }^{5}$ Aid to the Blind $(A B),{ }^{6}$ Aid to the Permanently and Totally Disabled (APTD), ${ }^{7}$ and Aid to Families with Dependent Children (AFDC) ${ }^{8}$

1. See J. Wedemeyer \& P. Moore, The American Welfare System, 54 Calif. L. Rev. 326 (1966), for a detailed discussion of the structure of the American welfare system.

2. Id. at 333-34.

3. For a treatment of some problems in judicial review of general assistance sec D. Mandelker, Judicial Review in General Assistance, 6 J. PuB. L. 100 (1957). 1965).

4. Social Security Act of 1935, 42 U.S.C. \$§ 301-1394 (1964), as amended (Supp. I,

5. 42 U.S.C. $\$ \$ 301-06$ (1964), as amended (Supp. I, 1965).

6. 42 U.S.C. $\$ \$ 1201-06$ (1964), as anended (Supp. I, 1965).

7. 42 U.S.C. \$\$ 1351-55 (1964), as amended (Supp. I, 1965). The original act had no provisions for Aid to the Disabled. This provision was added in 1950. Social Sectrity Act Amendments of 1950, $\$ \S 1401-05,64$ Stat. 555.

8. 42 U.S.C. $\S \S 601-09$ (1964), as amended (Supp. I, 1965). The provisions of this section were substantially extended in 1961 to enable states to give aid to families where the only reason for lack of parental support is the unemployment of the parent. 42 U.S.C. $\S 607$ (1964). 
Each joint state-federal program provides aid for needy persons within the statutory classification. AFDC, for example, authorizes federal support of state assistance to needy children (and in certain circumstances to those who care for them) when the children have been deprived of the care or support of one or both parents through death, physical or mental incapacity, or continued absence from the home. ${ }^{9}$

State participation is not required by the federal statute. States may choose not to apply for federal assistance or may join in some, but not all, of the programs. ${ }^{10}$ In order to receive federal funds, however, state plans must be submitted for the approval of the Secretary of Health, Education, and Welfare. ${ }^{11}$ Although the establishment of criteria for need and other factors of eligibility is left largely to the states, ${ }^{12}$ the plans must meet certain basic qualifications under the act ${ }^{13}$ and must conform to the rules and regulations promulgated by the Secretary. ${ }^{14}$ If at any time during the administration of a state plan the Secretary finds that there has been substantial noncompliance with the conditions imposed by statute or regulation, he "shall" cut off funds from the state. ${ }^{15}$ Such action may be taken only after the state has been afforded reasonable notice and an opportunity for a hearing to determine whether the plan is in conformity with federal requirements. ${ }^{16}$ From an adverse decision, the state may seek judicial review in the federal circuit courts. ${ }^{17}$

The state plans themselves are usually devised pursuant to general enabling legislation empowering a state agency to promulgate rules and regulations for administering the federal program. ${ }^{18}$ Such legislation usually au-

9. 42 U.S.C. $\S 606$ (Supp. I, 1965).

10. See 42 U.S.C. $\$ \$ 301,601,1201,1351$ (1964). See also Carmichael v. Southern Coal \& Coke Co., 301 U.S. 495, 525-26 (1937) (title III of the original act providing for federal aid to state unemployment compensation plans was not coercive in its effect on the state).

11. 42 U.S.C. $\S \S 301,601,1201,1351$ (1964).

12. See House Comm. on Ways and Means, The Social Security Bill, H.R. Rep. No. 615, 74th Cong., 1st Sess. 18, 24 (1935); Senate Comas. on Finance, The Social Security Bill, S. Rep. No. 628, 74th Cong., 1st Sess. 29, 36, 52 (1935).

13. State plans for each of the four major programs must: (a) be in effect in all subdivisions of the state; (b) provide for financial participation by the state; (c) establish or designate a single state agency for administration of the plan; (d) give opportunity for a fair hearing within a reasonable period of time to individuals whose claims are either denied or not acted upon within a reasonable period of time; (e) provide for such methods of administration as are found by the Secretary of Health, Education, and Welfare to be necessary for proper and efficient administration of the state plan; (f) provide for periodic reports as required by the Secretary; (g) provide for taking into consideration all non-exempt income of claimants; (h) provide safeguards on disclosure of information about applicants and recipients; (i) provide that all who wish to apply may do so; (j) provide for descriptions of services available from the agency. In addition, other requirements peculiar to each of the various programs are set forth. 42 U.S.C. $\S \S 302,602,1202,1352$ (Supp. I, 1965).

14. 42 U.S.C. \& $1302(1964)$.

15. 42 U.S.C. $\$ \$ 304,604,1204,1354$ (1964).

16. 42 U.S.C. $\$ \$ 304,604,1204,1354$ (1964).

17. 42 U.S.C. \& 1316 (Supp. I, 1965).

18. See, e.g., LA. Rev. Stat. \& 46:51 (1950); Mich. Stat. ANn, § 16.401 (1960); N.Y. Soc. Welfare LaW $\$ \$ 18,20$; PA. Stat. ANN. tit. 62, \$ 2504 (Supp. 1965); S.C. CODE ANN. \$ 71-9 (1962). Compare N.Y. SOC. WELFARE LAw which is very detailed in its provisions with LA. REV. STAT. \$§ 46:51-68 (1950). 
thiorizes the agency to create a plan for federal approval; indeed, some statutes specifically charge the agency to do whatever is necessary to ensure continued receipt of federal funds. ${ }^{19}$ The procedures employed by the state agencies generally contain certain basic elements. Thus, the federal act requires the state to accord a "fair hearing" before the agency to persons who are denied assistance. ${ }^{20}$ And although few states provide explicitly for judicial review of agency action, ${ }^{21}$ state court review is, in fact, usually ávailable-either through the operation of a state administrative procedure act or by virtue of general judicial or statutory principles controlling the review of administrative action.

Apart from those procedures which are specifically set forth in the federal statute, or represent the common response of the states to an ever present problem, the state programs vary considerably with regard to their standards of eligibility and methods of administration. Most of these variations represent legitimate exercises of the extensive discretion contemplated by Congress, ${ }^{22}$ but some state welfare provisions may be violative of the United States Constitution, the Social Security Act, or the binding regulations of the Department of Health, Education, and Welfare.

\section{The Substantive Issues}

A few illustrations of common state welfare regulations with potentially illegal characteristics should suffice to indicate the nature of the issues which welfare claimants might seek to litigate in federal court. ${ }^{23}$ The doubtful legality of two provisions- "midnight scarches" and "suitable home" policies"

19. E.g., Ga. CODE ANN. § 99-2915 (Supp. 1966).

20. State statutes requiring fair hearings include LA. REv. Stat. \$ 46:107 (1950), providing for appeal "in the manner and form prescribed by the state department. . ."; MICH. STAT. ANN. \& 16.409 (1960), providing for "a fair hearing of appeals and complaints, when requested in writing by any applicant for or recipient of assistance or service, financed in whole or in part by federal funds."; N.Y. SOC. WELFARE LAW $\S \S 213(2), 293(1),(3), 304(4), 353(2)$; S.C. CODE ANN. \$\$ 71-54, 71-55 (1962).

21. See ConN. Gen. Stat. ANN. \& 17-2b (Supp. 1965) ("Such decision [of the commissioner] after hearing shall be final except that the applicant for such hearing, if aggrieved, may appeal therefrom ... to the circuit court in any circuit in the county wherein he resides ...."); CAL. WELfare AND INST'NS Code $\$ 10962$ (". . the applicant or recipient or the affected county ... may file a petition with the superior court ...".). But see GA. CODE ANN. \& 99-2911 (Supp. 1965) ("The decision of the Director of the Department of Family and Children Services on any appeal shall be final.") ; PA. STAT. ANN. tit. 62, $\S 2507$ (e) (Supp. 1965) (providing that decisions on fair hearings, with one limited exception, shall be "final." Of course, the interpretation given to the word "final" is crucial as to whether review will be granted for abuse of discretion or for a decision not resting on substantial evidence.).

22. "Less Federal control is provided than in any recent Federal aid law." S. REp. No. 628 , 74th Cong., 1st Sess. 4 (1935).

23. For other substantive problems, see, e.g., B. Harvith, The Constitutionality of Residence Tests for General and Categorical Assistance Programs, 54 CALIF. L. Rev. 567 (1966); R. O'Neil, Unconstitutional Conditions: Welfare Benefits veith Strings Attached, 54 CAL.F. L. REv. 443 (1966); C. Reich, Individual Rights and Social Welfare: The Emerging Legal Issues, 74 Y ALE. L.J. 1245 (1965); E. Sparer, Social Welfare Law Testing, 12 Prac. Law. 13 (1966).

24. On midnight searches, see C. Reich, Midnight Welfare Searches and the Social 
- has been noted by some authors, although neither of these techniques has been the subject of direct attack in the courts. ${ }^{25}$ State practices denying aid to needy children who live in "unsuitable homes" have been substantially curtailed both by HEW regulation and by congressional enactment. ${ }^{26}$ And HEW has also recognized that midnight searches may often infringe upon the welfare recipient's fourth amendment rights; administrative rulings to guard against such abuses have been promulgated, and will soon go into effect. ${ }^{27}$ Nevertheless, prior to these recent statutory and regulatory changes, both practices had continued unhampered and generally unnoticed for many years. ${ }^{28}$.

Other serious substantive problems have received even less attention. For example, approximately one-third of all states fix the maximum amount of grants to families with dependent children. ${ }^{29} \mathrm{~A}$ typical regulation reads:

The maximum grants in AFDC are $\$ 36$ for the first child, $\$ 27$ for each additional child, $\$ 27$ for a caretaker, and $\$ 27$ for a second parent, up to and not to exceed $\$ 144$ per family per month. ${ }^{30}$

Security Act, 72 Y ALE L.J. 1347 (1963). On suitable home policies see Note, Suitable Home Tests Under Social Security: A Functional Approach to Equal Protection, 70 Yale L.J. 1192 (1961). See also W. Bell, Aid to Dependent Children (1965). The midnight search issue arises through operation of one of the many variations of the "man in the house" rule. The welfare claimant signs a blanket agreement to cooperate with the agency. Subsequently, agency investigators or social workers come late at night or very early in the morning and either ask or demand entry to determme whether any illicit relationship which might cause aid to be demed is going on. Inplicit, or often explicit, is the threat that aid will be cut off if the recipient does not "cooperate" by consenting to the search. Suitable home policies prior to 1962 consisted of determining that a certain factor, or factors, would in itself render a home unsuitable. Thus, Louisiana determined that homes with illegitimate children were "unsuitable" and terminated aid primarily on that basis. W. BeLL, supra at 137-38.

25. The midnight search question has, however, been raised as a central issue im Parrish v. Civil Service Comm'n, 51 Cal. Rptr. 589 (Dist. Ct. App. 1966). A social worker has sued to regain his job after having been fired for refusing to participate in midnight "bed checks." The California Court of Appeals held that such searches when, as in this case, warning was given that it was not necessary to admit the searchers, did not violate the fourth amendment. Therefore, dismissal for not obeying instructions was justified.

26. The suitable home policy as applied in Louisiana was the subject of a major crisis in 1960 and 1961. The Secretary of Health, Education, and Welfare, Arthur Flemming, promulgated a ruling on Jan. 17, 1961, effective July 1, 1961, prohibiting state plans from imposing suitable home policies as a basis for denial of assistance without making adequate provisions for the care of all children whose families were denied aid on this basis. W. BELL, supra note 24 , at $146-48$. The substance of the Flemming ruling was incorporated into the federal statute by 42 U.S.C. $\$ 604(\mathrm{~b})$ (1964).

27. A new regulation, effective July 1, 1967, may have the effect of outlawing midnight searches. UNITEd States Dep'T of HEalth, Education, aNd Welfare, HaNdBook of Public Assistance Administration, Part IV, Handbook Transmittal No. 77 (March 18, 1966) [hereinafter cited as FEDERAL HANDBOOK]. Section 2230 of the transmittal provides that states must guard against entering homes by force or without permission or under false pretenses, or at times outside of normal working hours, especially during sleeping hours. Because of the peculiar nature of the HEW Handbook of Public Assistance, it is difficult to tell which provisions are to be interpreted as mandates and which as recommendations. Since states are required to show evidence of compliance with this transmittal by submitting changes in state plans for approval by April 1, 1967, it is likely that at least some of the language in the regulation will be held binding.

28. For a history of the extensive use to which suitable home policies were put, especially in the South, to exclude large numbers of persons prior to the Louisiana crisis, see W. BELL, supra note 24 , at $93-110$.

29. E. Sparer, sitpra note 23, at 21.

30. Ga. Manual of Public Assistance, Part III, \& VII, at G-37 (1966) [hereinafter cited as GA. MANUAL]. 
A similar rule was held by the Iowa Supreme Court in Collins v. State Board of Social $W$ elfare ${ }^{31}$ to violate the equal protection clause of the Iowa Constitution. The court's holding that the regulation gave rise to an unreasonable classification between children of large and small families ${ }^{32}$ would seem to apply with equal force under the fourteenth amendment of the United States Constitution.

Several state welfare plans include "substitute father" rules. These provisions purport to be refinements of the federal statutory definition of "dependent child." The Social Security Act defines "dependent child" as a needy child "who has been deprived of parental support or care by reason of the death, continued absence from the home, or physical or mental incapacity of a parent ....."33 An example of a substitute father rule, though somewhat harsher than other such rules, is furnished by the following Arkansas regulation:

When a step-parent resides in the home, or when a parent maintains a stable non-legal union, "continued absence of a parent from the home" can no longer be considered as reason for deprivation. $A$ stable non-legal union is presumed, even though a father is not living contimuonsly in the home, where the mother affords the privileges of a husband to a man and there is a continuing relationship. ${ }^{34}$

It is arguable that the Arkansas rule has redefined the word "parent" to frustrate the purpose of the Social Security Act. The regulation denies aid to children who have in fact been deprived of parental support within the ordinary and accepted meaning of the word "parent." It does so, moreover, wholly by reference to the mother's social or sexual relations and without regard to the man's actual support of the children or the existence of any legal obligation on his part to provide such support. ${ }^{35}$

Still another potentially illegal regulation is the "employable mother" rule. A Georgia regulation, for example, requires an able-bodied mother who is not needed in the home to work if suitable employment is available."10 Suitable employment is defined as work consonant with her training and experience, within reasonable proximity to her home, and "in keeping with the prevailing wage scale and working conditions existing in the community."'37 A woman is "not needed in the home" when she can arrange to have her chil-

31. 248 Iowa 369,81 N.W.2d 4 (1957).

32. Id. at 377,81 N.W.2d at 9.

33. 42 U.S.C. $\$ 606$ (a) (1964).

34. Ark. Dep't of Public Welfare Manual 2813, at 1 (1966) (emphasis in original) [hereinafter cited as ARK. MANUAL].

35. Since the legislative history of the Social Security Act is unambiguous in stating that states could impose eligibility criteria on "moral" grounds, the argument presented here is hardly dispositive. S. REP. No. 628, 74th Cong., 1st Sess. 36 (1935); H.R. REp. No. 615, 74th Cong., 1st Sess. 24 (1935). Nevertheless, in light of the statutory adoption of the Flemming ruling (see note 26 stipra) it may be argued that if the state is to use such criteria, alternative provisions for the children so deprived of aid are necessary.

36. Ga. MANUal, Part III, \& V, at $8(2)$.

37. Id. 
dren cared for in her absence, when there is no child under three years of age, and when her presence is not required because of serious illness. ${ }^{38}$ The Georgia regulation is particularly harsh in that the mother's wages derived from full time employment, no matter how small, are exclusive; they will not ordinarily be supplemented by welfare payments. ${ }^{39}$ Thus, a woman earning $\$ 15$ to $\$ 20$ per week would not he entitled to any aid for her dependent children even though a needy family with four or more children would, by Georgia welfare budget standards, normally be entitled to $\$ 144$ per month.

The validity of the Georgia regulation is subject to both constitutional and statutory objections. It may be argued that in defining suitable work by reference to community standards the provision invidiously discriminates against Negroes, contrary to the equal protection clause of the fourteenth amendment. In many areas of the South, community mores sharply distinguish the work which is proper and suitable for whites from that which will do for Negroes. ${ }^{40}$ Furthermore, in withholding support from dependent children who otherwise qualify as needy under state standards merely because their mothers secure full time employment, the state has created a classification which does not appear to bear any reasonable relationship to the purposes of the statute and the program in general.11 The general prohibitions of the equal protection clause are not the sole source of federal standards for invalidating the employable mother rule. The legislative history of the Social Security Act clearly reveals that Congress wished the employable mother to retain the right to spend her time with her children rather than at work when the support of the father was not available. ${ }^{42}$ In addition, the Department of Health, Education, and Welfare's Handbook of Public Assistance Administration contains provisions which-while not phrased in mandatory terms-state that the purpose of AFDC is to allow a mother to choose between working and being with her family. ${ }^{43}$

Improper administration of an otherwise valid state plan may raise issues under the federal constitution or Social Security Act. Illegal practices may exist even where the state statute and regulations are, on their face, unexceptionable. The most common example is racial discrimination on the part of local administrators. ${ }^{44}$ Such a practice-even if specifically proscribed by the state plan-would constitute a violation of Title VI of the Civil Rights Act of

38. Id.

39. Id. at $9(3)$. The Georgia regulation is unusual in that the no-supplementation rule is not often found in conjunction with employable mother rules in other states.

40. See, e.g., the Albany [Ga.] Herald which has classified advertisements which overtly distinguish between positions available to whites and those available to Negroes. Albany (Ga.) Herald, Jan. 5, 1967, at 1D, col. 5; id., Jan. 3, 1967, at 7, col. 5 .

41. See Brief for Plaintiff, Anderson v. Schaeffer, Civil No. 10443 (N.D. Ga., filed Sept. 20, 1966), for a complete exposition of the arguments against the rule.

42. See S. Rep. No. 628, 74th Cong., 1st Sess. 36 (1935).

43. FEDERAL HaNDBOoK, Part IV, \& 3401.

44. The Georgia employable mother rule, Ga. Manuat, Part III, § V, at $8(2)$, provides ample opportunity for racial discrimination by local officials. 
1964 which prohibits the use of federal money in a discriminatory manner. ${ }^{45}$ Local discrimination would also contravene the sections of the Social Security Act calling for uniform implementation of a state plan within all political subdivisions of the state. ${ }^{46}$ Occasionally, a local welfare board on its own initiative adopts a very restrictive policy. Fearing federal intervention, the state agency will usually act to remedy such aberrations. ${ }^{47}$ If it fails to maintain the standards of its own plan, however, its inaction will lead to an infraction of the provision of the federal statute requiring uniform application.

\section{Agencies and Clatmants: The Motives for Seetring Federal Judictal Review}

In the thirty-one year history of categorical assistance there have been few attempts by dissatisfied claimants to secure judicial review of the validity of state provisions. ${ }^{48}$ Because of the intimidating nature of the welfare structure, the general unavailability of legal assistance, and the indigency-and often illiteracy -of the claimant, available remedies have not been utilized to their fullest extent. However, it is likely that the courts will soon face a significant increase in litigation in this area. Organizations of welfare recipients and claimants are being generated at an accelerating pace in virtually every large city in the country. Some of these groups are the products of indigenous community leadership; others have been formed by student activist groups or through community action programs under private or governmental auspices. ${ }^{49}$ It is becoming apparent that these community organizations will soon undertake large scale efforts to challenge the most glaring abuses through the courts-in particular, the federal courts-as well as by direct action and political persuasion..$^{50}$ In order to appreciate why these groups prefer a federal judicial forum for the resolution of the issues raised by the administration of welfare programs, some understanding is necessary of the rules and procedures of the various administrative agencies which are involved in the process.

45. 42 U.S.C. \& 2000d (1964).

46. 42 U.S.C. $\S \S 302$ (a) (1), 602(a) (1), 1202 (a) (1), 1352(a) (1) (1964).

47. See State Bd. of Social Welfare v. City of Newburgh, 28 Misc. $2 d 539,220$ N.Y.S.2d 54 (Sup. Ct. 1961).

48. J. Yasui, Fair Hearings in Public Assistance 90-91 (1966) (unpublished thesis in Graduate Dep't of Social Work and Social Research of Bryn Mawr College).

49. The organization of welfare recipients' groups can be considered to have started with the Welfare Rights Organization (WRO) in Oakland, Cal. However, many local civil rights movements in the South have been encouraging such organization for several years. At present, groups of various size and strength exist in Chicago, Cleveland, New York, Newark, Oakland, Albany (Ga.), Atlanta, and Washington, D.C., as well as in other cities.

50. Several cases are already at various stages in the judicial process. E.g., Smith v. Board of Comm'rs, 259 F. Supp. 423 (D.D.C. 1966); Anderson v. Schaeffer, Civil No. 10443 (N.D. Ga., filed Sept 20, 1966) (challenge to the Georgia employable mother rule); Smith v. King, Civil No. 2495-N (M.D. Ala., filed Dec. 2, 1966) (challenge to Alabama substitute father rule). 


\section{A. Inadequacy of the Federal Administrative Forum}

The Department of Health, Education, and Welfare has been extremely reluctant to apply the drastic sanction of cutting off federal funds where state plans may be operating inconsistently with federal law. ${ }^{51}$ In thirty years of administration of the Social Security Act by the Department and its predecessors, only sixteen conformity hearings have been ordered. ${ }^{52}$ The Department prefers whenever possible to settle its differences with the states through negotiation. ${ }^{53}$ Indeed, it has been reluctant to cut off funds even when there has been wholesale exclusion of large classes of persons from welfare hists, preferring instead to clarify federal requirements through the promulgation of regulations prospective in effect. ${ }^{54}$ While such a policy avoids disrupting the limited assistance still available to some people even in the most flagrant cases of abuse, it does little to ensure efficient application of the mechanisms intended to safeguard the interests of persons who have been excluded. Moreover, even in those cases in which HEW action has been effective in curbing certain questionable state practices, relief has come only after long delay. The Department's efforts to mitigate the suitable home and midnight scarch policies, for example, were instigated only after those practices had received extensive critical publicity.

The most serious inadequacy of the Department of Health, Education, and Welfare as a guarantor of the protections afforded by federal law is the absence of a formal means by which the dissatisfied individual can bring his claim before the federal agency. The Social Security Act and the HEW regulations do not provide procedures for the filing of complaints or appeals with the Department. The only formal effort by individuals to force action by the Department has failed. An application by Georgia and Arkansas claimants for a conformity hearing to determine the legality of the Georgia and Arkansas substitute father rules was submitted to the Department in 1966. No action or response from the agency lias yet been received. ${ }^{55}$ Altliough no statute authorizes the Department to act as a general review board for state administrative decisions concerning the alleged invalidity of a welfare provision, nothing in the act would prevent the federal agency from adopting a procedure

51. See J. Wedemeyer \& P. Moore, supra note 1, at 342; W. BELL, supra note 24, at 223 n.33.

52. W. BeLr, sipra note 24 , at 223 n.33.

53. "In practice, hearings have been extremely rare. They are not held until after reasonable effort has been made by regional and central office representatives to resolve the questions involved by conference and discussion with State officials." FeDERAL HANDBOoK, Part I, \& 4300 .

54. See W. BELI, supra note 24 , at $137-51$.

55. See Complaint and Petition for a Hearing Pursuant to $\S 404$ of the Social Security Act, Johnson v. Department of Pub. Welfare (HEW, filed Feb. 1966). Conversations with Attorney C. B. King, counsel for the Georgia complainant, indicate that no response has been received from the Department as yet. 
whereby claims of nonconformity would be processed and decided. While complete appellate review of state fair hearing determinations would be undesirable and might exceed the Department's authority, there is no barrier to the use of dissatisfied claimants as one of many sources of information as to the conformity of state plans.

\section{B. The Need for Judicial Review of State Welfare Programs}

The benefits which attach to judicial review of administrative action in general-preservation of the rule of law, prevention of arbitrariness, and assurance of ultimate recourse to a completely disinterested decision-making body-apply as well to the review of state welfare administration. In addition to these considerations, however, the peculiar nature of the welfare agencies, and of the plight of the claimants, magnifies the need for ensuring the availability of a judicial forum to test the legality of certain aspects of state welfare plans.

The "fair hearing" procedures of some states are entirely unsatisfactory as final adjudicatory proceedings, for they do not permit challenges to the validity of regulations which are of general applicability. Thus, two state agencies-apparently the only ones to consider the question-have held that they have no power to decide upon the legality of such provisions. ${ }^{50}$ In jurisdictions where this rule prevails, the claimant who does not dispute the applicability of the regulation to him, but only claims that it is illegal, can obtain no relief at the fair hearing.

Even if the agency does not disqualify itself from considering the validity of welfare regulations, there remain several barriers to obtaining an effective adjudication on the merits. The persons responsible for the final decision in a fair hearing are generally the persons who have promulgated the regulations under attack. ${ }^{57}$ Moreover, the hearings are informal proceedings and certain types of relief which would be appropriate for implementing an adjudication on the legality of the regulation-injunctions and declaratory judgments, for example-are not available from the agency. These and other factors permit an agency which is motivated by bad faith or considerations of expediency ${ }^{68}$ to dispose of a case on some frivolous or non-existent factual ground, thus avoiding a decision upon the validity of the regulation.

Another significant obstacle to obtaining an agency determination of the

56. See Memorandum of Decision, Request of Miss Dorothy Reed, Case No. 92-C-74675 (August 22, 1966), Conn. State Welfare Dep't; Decision in Regard to Appeai for Fair Hearing in the Case of Mrs. Ovelia Robinson, Newark, N.J., Case No. EC-9475 (April 4, 1966).

57. E.g., LA. REv. STAT. \$\$ 46:52, $46: 107$ (1950) ; N.Y. Soc. WeLfare LAW \$§ 18, 20, $213(2), 293(1),(3), 304(4), 353(2)$; S.C. CODE ANN. $\$ \$ 71-9,71-54,71-55$ (1962).

58. Many state welfare departments, like other state administrative agencies, are badly understaffed. 
legality of its regulations is that welfare claimants are generally not represented by counsel. Although the right to retain counsel is secured by federal regulations, ${ }^{59}$ and federal subsidies are available to states that wish to provide free legal services for those on welfare, ${ }^{60}$ few states do, in fact, provide such services. In the absence of state legal services, the assistance of counsel can rarely be obtained. Few claimants have the means to retain an attorney independently, and only a small minority have been able to rely upon government programs for legal aid or upon private individuals and organizations which are specifically involved in civil rights and civil liberties matters. ${ }^{61}$ Without a lawyer the lone claimant in a fair hearing will seldom know that the rule by which he was excluded is illegal, much less know how to go about challenging it.

The position of a claimant whose aid has been cut off or reduced is particularly precarious. Every day without the necessities of life creates an immediate and irreparable injury. And the initial cutting off of funds usually has permanent effect. HEW regulations do not require state agencies to restore payments that have been withheld even if it is determined at the fair hearing that the denial of aid was erroneous, ${ }^{62}$ and most states do not provide such reimbursement. ${ }^{63}$ Challenges to state welfare regulations are particularly unlikely when the questionable provision takes the form of a condition upon the receipt of aid-such as blanket cooperation clauses which agencies interpret to permit midnight searches-rather than the denial of aid to certain classes. The state is not required to provide a fair hearing when it imposes the condition, ${ }^{04}$ but only later, when aid has been reduced or cut off. Those who are receiving aid under such conditions are likely to submit to the restrictions, for a refusal to obey entails a prolonged confrontation with the agency during which the individual would have no means of support. In such circumstances, direct access to the courts would permit testing such provisions.

Another inadequacy of the administrative scheme is evident in comparison with judicial procedures. State welfare agencies do not provide a "class action" on the part of claimants wishing to challenge the validity of regulations. Yet, such an action would be the most efficient means for these economically

59. Federal HaNdBook, Part IV, § 6200 (3) (e).

60. Federal HandBook, Part IV, § 6400(2) (b).

61. The NAACP Legal Defense and Education Fund does reimburse cooperating attorneys for some work done for welfare claimants. The Columbia School of Social Work in cooperation with the Office of Economic Opportunity has recently established a center for social welfare law research which involves testing various welfare provisions. Individual attorneys and some neighborhood law programs established by OEO have shown progressively more interest in this area.

62. Federal HandBoox, Part IV, $\$ \$ 5413.2,5422$.

63. See, e.g., Ga. Manual, Part III, \& VIII, at 1 .

64. The statute provides for hearings if aid is denied or if decision is not made promptly. 42 U.S.C. \$ 302 (a) (4) (1964); 42 U.S.C. \$\$ 602 (a) (4), 1202 (a) (4), 1352 (a)(4) (Supp. I, 1965). 
dependent individuals to assert their collective grievances. The federal courts, by contrast, have accommodated their procedures in recognition of the fact that certain citizens are less able to protect their rights than others. Thus, in an analogous situation, the federal courts have allowed the class action to vindicate the rights of Negroes in school desegregation cases. ${ }^{05} \mathrm{~A}$ similar use of the class action would be a powerful weapon in testing the legality of state welfare regulations.

In some areas of the country the same factors which work to discourage minority groups generally from asserting their rights operate upon the welfare client as well. A disproportionately large percentage of welfare recipients are Negroes. ${ }^{60}$ Where discrimination is widespread, the client faces a predominantly white power structure within the agency which administers a program structured by a predominantly white legislature and supervised, if at all, by an all white judiciary. The likelihood that a Negro mother of several illegitimate children will, through such procedures, successfully challenge a regulation which may have been created precisely for the purpose of excluding her is not great. Even where discrimination and oppression is not overt, the bureaucratic system operates to discourage and intimidate many. ${ }^{07}$ It is not surprising, then, that fair hearings have rarely been used as a forum for attacking the validity of state welfare regulations. ${ }^{08}$

These difficulties are compounded by the most fundamental inadequacy of the state fair hearing procedure-that it generates no uniform and binding body of law delineating the permissible scope of administrative discretion. While federal regulations require that the claimant be afforded a record of the liearing, ${ }^{09}$ decisions are generally not published; thus, even assuming a fair and competent ad hoc adjudicative process, there is no assurance of consistent adherence to well-known principles or rules of decision. Moreover, regulations in both state and federal handbooks are not generally available to the public. Althougl the agency will provide a lawyer or claimant access to the particular regulations which the agency considers relevant to the case, the rules governing the general area involved are not made available, and meaningful legal research or argument is seriously hampered as a result.

65. E.g., Orleans Parish School Bd. v. Bush, 242 F.2d 156 (5th Cir.), cert. denicd, 354 U.S. 921 (1957).

66. I. Miller, Race and Poverty, 54 CalIF. L. Rev. 386, 397 (1966).

67. See S. Briar, Welfare From Below: Recipients' Viezes of the Public Welfare System, 54 CALIF. L. REv. 370 (1966). See especially the section on recipients' views of agency decision making. Id. at 377. In the author's sample $60 \%$ of the recipients reported that they had not been informed of their right to appeal. Id. at 379. The findings of this survey may not reflect the actual number of persons, who were told of their right to an appeal, for it must be recognized that the act of informing a client of this right often takes the form of reading aloud a long, legalistic document which, somewhere, speaks of a right to appeal. Scldom is the substance of the application form, ultimately signed or marked by the applicant, explained in plain English (or Spanish).

68. J. Yasui, supra note 48.

69. Federal Handbook, Part IV, § 6338. 


\section{The Advantages of Federal Judicial Review}

Judicial review would obviate many of the difficulties which stem from the absence, in the state administrative structure, of both stare decisis and an effective means for challenging regulations. Some of the needs for judicial review may be fulfilled by proceedings in state courts. However, review in the courts of some states is precluded by state law. And even where it is not, welfare claimants are nevertheless likely to prefer resolution of important constitutional and statutory issues by the federal judiciary.

One reason for this preference is that state courts in some parts of the country may fail to extend effective protection to the interests of Negro plaintiffs. Civil rights and civil liberties lawyers operating in the South believe that the federal judiciary there is, on the whole, more inclined to recognize and protect a Negro's interests than are certain state courts. ${ }^{70}$ Thus, to avoid possible racial discrimination, the welfare claimant would seek review in federal court.

Moreover, the legal questions which are presented by welfare cases are, for the most part, federal. The central issue is usually whether a state statute, regulation, or administrative practice violates the United States Constitution, the Social Security Act, or the HEW regulations. Even when a state court is asked to decide whether an agency regulation violates the state statute, the answer will often turn upon an interpretation of federal law. ${ }^{71}$ Not only are federal courts likely to be more familiar with the questions presented than are the state courts, but federal interpretation will lead to a more uniform application of the Social Security Act throughout the nation. While the structure of the act and its legislative history reflect a desire to permit many types of variations among the states, ${ }^{72}$ they also set forth certain minimum criteria to which all state plans must conform. ${ }^{73}$ Uniform adherence to these standards is easier to achieve through federal circuit court decisions; such rulings will control the adjudication of similar issues arising in federal courts construing the law of other states within the same circuit. They would also be more likely to be persuasive to federal courts in other areas than would state decisions on the same questions.

The relationship between the federal courts and the Department of Health, Education, and Welfare is far different from that between the state courts and the Department. Only the federal courts can compel remedial action on the

70. See, e.g., A. Amsterdam, Criminal Prosecutions Affecting Federally Guaranteed Civil Rights: Federal Removal and Habeas Corpus Jurisdiction to Abort State Court Trial, 113 U. PA. L. REv. 793 (1965).

71. See, e.g., State ex rel. Dean v. Brandjord, 108 Mont. 447, 92 P.2d 273 (1939) (holding that Montana statute incorporated, by implication, the requirements of the Social Security Act as binding upon the state agency).

72. H.R. REP. No. 615, 74th Cong., 1st Sess. 17-18, 24 (1935); S. REP. No. 628, 74th Cong., 1st Sess. 4 (1935).

73. Id. 
part of HEW when such relief is sought. Moreover, federal court decisions are likely to have significant influence upon the Department even when it is not made a party to the action. A state court holding that a regulation was invalid under the federal constitution would be unlikely to influence HEW to the same extent as the same determination by a federal court, particularly if the unconstitutionality were not patently clear.

The methods by which state welfare programs may be challenged in federal court will vary with the nature of the illegality asserted and the relief requested. Suits to enjoin the enforcement of an allegedly unconstitutional state practice or regulation can be brought directly against the state officials under 42 U.S.C. $\S 1983$. Secondly, the same relief can be sought under section 1983 on a claim that the state regulation violates the Social Security Act or HEW regulations. Finally, suit may be brought in the federal court against the Secretary of Health, Education, and Welfare to compel him to determine whether the state plan complies with mandatory federal requirements and to cut off funds if he finds non-conformity.

\section{Constitutional Challenges to State Welfare Practices}

If a substantial constitutional attack can be mounted against a state welfare regulation or administrative practice, the injured welfare claimant can bring an action against the responsible state officials under section 1983:

Every person who, under color of any statute, ordinance, regulation, custom, or usage, of any State or Territory, subjects, or causes to be subjected, any citizen of the United States or other person within the jurisdiction thereof to the deprivation of any rights, privileges, or immunities secured by the Constitution and laws, shall be liable to the party injured in an action at law, suit in equity, or other proper proceeding for redress. ${ }^{74}$

If it could be proved, for example, that an "employable mother" rule was intended to, and did in fact, discriminate against Negro claimants in violation of the fourteenth amendment, ${ }^{75}$ an injunction could be obtained restraining further enforcement of the unconstitutional regulation. ${ }^{76}$ Jurisdiction of the

74. 42 U.S.C. \$ 1983 (1964).

75. See note 40 supra and accompanying text. While $\S 1983$ has at times been restrictively interpreted to exclude equal protection cases, see Bottone v. Lindsley, 170 F.2d 705 (10th Cir. 1948), cert. denied, 336 U.S. 944 (1949), recent decisions have probably abandoned such restrictions. The reapportionment cases and school desegregation cases, as well as brutality cases, are now brought under this section. See, e.g., McNeese v. Board of Educ., 373 U.S. 668 (1963); Baker v. Carr, 369 U.S. 186 (1962); Monroe v. Pape, 365 U.S. 167 (1961). Racial discrimination would also constitute a clear violation of title VI of the 1964 Civil Rights Act, 42 U.S.C. $\$ \S 2000 \mathrm{~d}$ to -4 (1964).

76. Damages and, in some cases, punitive damages are available as a remedy under § 1983. Basista v. Weir, 340 F.2d 74 (3d Cir. 1965). Ncvertheless, as a practical matter, asking such relief would, in most welfare cases, be inadvisable. The primary objective is to remove the operation of an illegal regulation. Only an injunction or declaratory judgment will directly accomplish this purpose. Courts may be reluctant to assess damages against one who was carrying out a regulation formulated by his superiors. 
federal district court over such a cause of action would clearly exist under section 1343(3) of the Judicial Code, ${ }^{77}$ and there would be no need to establish that the amount in controversy exceeded $\$ 10,000 .^{78}$

There are only two potential obstacles to effective vindication of constitutional claims in the federal courts. Under the judicially developed doctrine of abstention, a federal court could refrain from exercising its jurisdiction in order to allow the state courts to resolve issues of state law which might render a determination of the constitutional issues unnecessary. In addition, the welfare claimant may be obliged to exhaust certain administrative remedies before state or federal agencies. Finally, if these two barriers are overcome, there remains the further question whether a three-judge district court may be obtained in such cases.

\section{A. The Doctrine of Abstention}

A rule requiring a federal court to abstain from exercising its jurisdiction in order to allow a state court to interpret the challenged law in a manner which avoids constitutional difficulties would preclude effective federal judicial review. Claimants who did not receive outside aid could rarely afford the delay until the state court had acted and the constitutional issue reached the Supreme Court from the state courts or became ripe for adjudication in the district court. An even more undesirable consequence of abstention, however, is that the state court would probably construe the regulation to avoid constitutional objections by holding it either inapplicable to the plaintiff or unauthorized by the state statute; if so, a federal determination of the constitutional issue would not take place, and the effectiveness of the suit as a test case for the benefit of all welfare claimants would be destroyed. ${ }^{79}$

The doctrine of abstention is founded upon the general policy of avoiding unnecessary constitutional determinations. ${ }^{80}$ As outlined by the Supreme Court in Railroad Commission v. Pullman ${ }^{81}$ and Burford v. Sun Oil Co.,82 the doctrine provides that a federal court should decline to exercise its jurisdiction if three factors are presented in a case. First, the precise meaning of

77. The district courts shall have original jurisdiction of any civil action authorized by law to be commenced by any person:

(3) To redress the deprivation, under color of any State law, statute, ordinance, regulation, custom or usage, of any right, privilege or immunity secured by the Constitution of the United States or by any Act of Congress providing for equal rights of citizens or of all persons within the jurisdiction of the United States.....

28 U.S.C. \& 1343 (1964).

78. See, e.g., Douglas v. City of Jeannette, 319 U.S. 157 (1943).

79. It is, of course, not unheard of for an administrator to seek to avoid, in any way possible, an adjudication of possibly illegal action. See Note, Mootness and Ripeness: The Postman Always Rings Trevice, 65 CoLuM. L. Rev. 867 (1965).

80. Ashwander v. TVA, 297 U.S. 288, 346-48 (1936) (Brandeis, J., concurring).

81. 312 U.S. 496 (1941).

82. 319 U.S. 315 (1943). 
the state law and its application to the facts in question must be unclear so that the state court could reasonably interpret the act to obviate constitutional issues. Second, since abstention seeks to avoid friction with state courts and interference with legitimate state interests, the subject matter of the litigation should involve substantial questions of state public policy. Finally, the federal court must be satisfied that the state judicial remedy is adequate to prevent irreparable injury to the plaintiff and to protect his constitutional claim. Subsequent decisions applying the doctrine failed to adhere strictly to each of these prerequisites. In several cases abstention was held appropriate even though the application of state law was unambiguous; the courts stressed that no state court had yet construed the statute and that the fecleral right would be fully protected pending the state action. ${ }^{83}$ However, even this latter factor has at times been ignored. ${ }^{84}$

Abstention has been rigidly applied in some suits brought under section 1983. Thus, in Harrison v. NAACP ${ }^{85}$ the Supreme Court held that the district court should have refrained from considering the constitutionality of several Virginia statutes prohibiting solicitation of litigation concerning racial integration. Although the district court had found clear first and fourteenth amendment violations, ${ }^{86}$ the Supreme Court ruled that abstention was necessary since the Virginia courts, if afforded an opportunity to pass on the question, might construe away the constitutional defects. The Court empbasized that the district court could safeguard the plaintiffs' constitutional rights by restraining enforcement of the statutes during the litigation in the state courts. ${ }^{87}$

Three dissenting justices in Harrison argued that a suit brought under section 1983 is never an appropriate vehicle for abstention. ${ }^{88}$ While the Supreme Court has yet to lay down such an explicit broad pronouncement, recent decisions have seriously undermined the applicability of the doctrine to cases asserting deprivation of the personal rights and liberties protected by section 1983. The Court has repeatedly emphasized that abstention is "not an automatic rule applied whenever a federal court is faced with a doubtful issue of state law ; it rather involves a discretionary exercise of a court's equity powers." ${ }^{39}$ Moreover, the Court has made it clear that a federal court should not decline to exercise its jurisdiction merely because the plaintiff could obtain adequate redress under state law-that the doctrine does not require

83. See Martin v. Creasy, 360 U.S. 219 (1959); Alabama Pub. Serv. Comm'n v. Southern Ry., 341 U.S. 341 (1951).

84. See Williams v. Hot Shoppes, Inc., 293 F.2d 835 (D.C. Cir. 1961), cert. devied, 370 U.S. 925 (1962).

85. 360 U.S. 167 (1959).

86. NAACP v. Patty, 159 F. Supp. 503, 528-29 (D. Va. 1958).

87. 360 U.S. at 179

88. Id. at 179-81 (Douglas, J., dissenting).

89. Baggett v. Bullitt, 377 U.S. 360, 375 (1964). Sec also Harman v. Forssenius, 380 U.S. 528, 534-37 (1965). 
exbaustion of all state remedies..$^{90}$ There must be "strands of local law woven into the case," ${ }^{\prime 11}$ and they cannot be subsidiary issues or questions of negligible interest to the state. Indeed, in one recent decision in which abstention was held improper, the Supreme Court emphasized that the federal determination, though involving aspects of state law, would not "work a disruption of an entire legislative scheme of regulation."

The Court has also stressed as a prerequisite to abstention that the meaning and application of state law be truly unclear and susceptible to legitimate construction which would save it from constitutional objection. The mere absence of a prior interpretation by the state courts is no longer sufficient..$^{93}$ Nor need the state statute or regulation appear unconstitutional on its face; the federal court can itself determine that the effect as applied is a deprivation of the plaintiff's constitutional rights. ${ }^{94}$ Indeed, the Court has suggested that generally the type of ambiguity which will support a decision to abstain is uncertainty as to whether the state rule applies to the complaining party, not a mere lack of clarity as to its precise meaning..$^{95}$ Finally, when the state law is attacked on grounds of vagueness, abstention has been held inappropriate since this constitutional defect cannot be cured by any single state court interpretation. ${ }^{08}$

Another aspect of the trend away from strict application of the abstention doctrine has been the Court's growing reluctance to assume that adequate protection will be provided against irreparable injury which may result from the purported violation of the litigant's constitutional rights pending the state court proceedings. Indeed, the threat to some fundamental rights has been deemed so pernicious that sufficient imterim protection is presumed impossible. Thus, the Supreme Court has crcated a blanket exception from the abstention rule for actions alleging deprivations of free speech, ${ }^{97}$ not only because of the immediate harm to the plaintiffs, but primarily because of the widespread "chilling" effect upon free exercise of the right. ${ }^{98}$. The dangers of delay and

90. See McNeese v. Board of Educ., 373 U.S. 668 (1963) ; Monroe v. Pape, 365 U.S. 167 (1961); Rivers v. Royster, 360 F.2d 592 (4th Cir. 1966); Powell v. Workmen's Compensation Bd., 327 F.2d 131 (2d Cir. 1964). Language to this effect in the Monroe decision has been read as destroying the doctrine as to $\$ 1983$ cases. See Comment, The Civil Rights Acts and Mr. Monroe, 49 CALIF. L. REv. 145, 169 (1961). That the plaintiff need not seek redress in the state courts before bringing suit under $\$ 1983$, however, does not necessarily preclude abstention in order to avoid an unconstitutional construction of an unclear state law.

91. McNeese v. Board of Educ., 373 U.S. 668, 673 (1963).

92. Hostetter v. Idlewild Bon Voyage Liquor Corp., 377 U.S. 324, 329 (1964).

93. Harman v. Forssenius, 380 U.S. 528, 534-35 (1965). (1964).

94. Cameron v. Johnson, 381 U.S. 741 (1965); Baggett v. Bullitt; 377 U.S. 360

95. Baggett v. Bullitt, 377 U.S. 360, 376-77 (1964).

96. Dombrowski v. Pfister, 380 U.S. 479, 490-91 (1965) ; Baggett v. Bullitt, 377 U.S. 360,378 (1964).

97. See Dombrowski v. Pfister, 380 U.S. 479, 483-92 (1965). See also Harman v. Forssenius, 380 U.S. 528 (1965) (reluctance to abstain in voting rights cases); McNeese v. Board of Educ., 373 U.S. 668 (1963) (reluctance in school desegregation situations).

98. Dombrowski v. Pfister, 380 U.S. 479, 487 (1965). 
the immediacy of the need for relief have thus become predominant factors in the federal court's decision whether to abstain. In short, the Supreme Court's consistent refusal since 1960 to require abstention in section 1983 cases suggests that the position of the dissenters in Harrison v. NAACP may have carried the day.

Assuming that the abstention doctrine retains some vitality in section 1983 cases, its application to suits by welfare claimants would nevertheless be inappropriate in most cases. In the first place, the meaning of a welfare regulation is usually clear on its face, and the applicability of the challenged rule to the plaintiff is not likely to be uncertain. If the regulation incorporates an imprecise exclusionary standard which may be used arbitrarily or discriminatorily-a "suitable home" policy perhaps-it might be attacked on grounds of vagueness, again rendering abstention improper. Secondly, a federal decision would not disrupt a regulatory scheme in which the state has a substantial interest. The questions presented are generally federal; indeed, many welfare decisions by state courts have been based primarily upon federal rather than state substantive law..$^{99}$ There is little danger of conflicting state and federal interpretations of state law, for state welfare programs-unlike the statutory schemes considered in the Pullman and Burford decisions ${ }^{100}$ involve no complex and purely local policies and are, for the most part, merely statutory adoptions of the federal program. While the states are accorded wide discretion in formulating such rules, ${ }^{101}$ there will, nevertheless, be little reason for the district court to stay its hand. The regulation's applicability to the plaintiffs will rarely be in question, and the only other probable route by which the state court could avoid constitutional objections would be by invalidation under the federal act or its equivalent-the state enabling statute which incorporates the federal act.

The most compelling reason for the federal court to exercise its jurisdiction over welfare suits under section 1983 is the immediate and irreparable harm suffered by the plaintiff unconstitutionally cut off from aid. This injury is not prevented pending litigation in the state courts, for the claimant cannot seek review until his aid has been severed and back payments are not afforded by most states. ${ }^{102}$ Thus, the two considerations which have persuaded the Supreme Court not to require abstention in other areas-delay and immediacy

99. See, e.g., Pearson v. State Social Welfare Bd., 54 Cal. 2d 184, 353 P.2d 33, 5 Cal. Rptr. 553 (1960) (upholding a California regulation principally on ground that federal law mandated the regulation); State ex rel. Dean v. Brandjord, 108 Mont. 447, 92 P.2d 273 (1939).

100. In Pullman, the State of Texas was held to have an interest in determining the powers of its regulatory Commission since it was unclear to what extent the decision made was within the jurisdiction of the administrative body. 312 U.S. at 499-500. In Burford, the Texas statutory scheme was a complex one dealing with the conservation of natural resources within the state. 319 U.S. at 318-19.

101. See note 22 supra and accompanying text.

102. See notes $22-24$ sipra and accompanying text. 
of the need for relief-are present in even greater measure in the case of the welfare claimant. ${ }^{103}$ It is true that where welfare recipients bring section 1983 suits to challenge unconstitutional conditions which they have not yet violated - to contest the validity of midnight search policies, for example- the plaintiffs suffer no concrete financial injury. But such conditions may be said to create pressures on welfare claimants analogous to the "chilling effects" of strictures upon first amendment rights. ${ }^{104}$ While such potentially unconstitutional conditions remain in force, the individual's fear of losing welfare support stifles exercise of fourth amendment rights in the same way that the threat of criminal sanctions or loss of employment dampens free speech. Federal abstention would be equally improper in one case as it is in the other.

\section{B. Exhaustion of Administrative Remedies}

Must the claimant undergo a fair hearing before the state or local agency prior to prosecuting a section 1983 action in the federal district court? Such a requirement would have the same disadvantages for welfare claimants as a decision by the federal court to abstain: the economic hardship of the delay would impose a steep barrier to effective relief, and adjudication of the claim by the agency would unnecessarily postpone federal judicial determination of the ultimate constitutional issues. Nevertheless, the well-settled general rule is that recourse to a federal court for review of an administrative decisionby either a state or federal agency-is proper only after all available adininistrative remedies have been exhausted. ${ }^{105}$

For the adjudication of the usual claim of illegal exclusion from assistance,

103. It may be argued that the federal court, while abstaining from a consideration of the merits, could, nevertheless, order that welfare payments be continued during the state action. Some support for such a view can be gleaned from the Supreme Court's observation in Harrison v. NAACP, 360 U.S. 167, 179 (1959), that the district court could thus protect the plaintiffs by teinporarily restraining enforcement of the allegedly unconstitutional criminal statute. The analogy, however, is somewhat infirm, and the court is unlikely to make such an order requiring the affirmative payment of state funds which have been cut off or denied by a presumptively lawful administrative deterinination.

104. The pressures upon the welfare claimant to sacrifice his constitutional rights do not constitute "chilling effects" within the precise meaning of the phrase as used by the Supreme Court in Dombrowski. To date, the Court has applied the doctrine only in first amendment cases because only there does the total harm to society from the regulation of free expression exceed the sum of individual injuries to those oppressed. In other words, the first amendment is deemed to serve societal values beyond the merely personal rights to freedom-the entire political process depends upon it. To the extent that the doctrine is founded upon that principle, its application is limited to the narrow confines of a situation such as that in Dombrozuski. Nevertheless, "chilling" is rooted in the problems of timing of federal review of state imposed sanctions on the exercise of constitutional rights. Thus, the doctrine is aimed at alleviating the damage to all individuals subject to sanctions caused by their mere existence, which may deter the legitinate exercise of constitutional rights. "The threat of sanctions may deter $\ldots$ almost as potently as the actual application of sanctions." NAACP v. Button, 371 U.S. 415,433 (1963). In this limited respect, welfare regulations which are applied to threaten the loss of aid unless basic constitutional rights are waived do impose a "chilling effect" similar to that of criminal statutes designed to curb first amendment privileges.

105. See, e.g., Public Serv. Comm'n v. Wycoff Co., 344 U.S. 237 (1952) ; Myers v. Bethlehem Shipbuilding Corp., 303 U.S. 41, 50-51 (1938). 
the state agency theoretically provides an adequate remedy. All states are required, both by statute and regulation, to hold some form of fair hearing whenever aid has been denied, cut off, or reduced. ${ }^{106}$ By HEW regulation, the fair hearing decisions must be binding upon both local and state agencies. $^{107}$ Moreover, most states prescribe that the hearing be held promptly after an appeal is taken and that the decision be rendered soon after the hearing. ${ }^{108}$ Thus, in theory, a complete and expeditious remedy is available for any allegation that loss of aid resulted from an erroneous factual determination of the administrator. As to most of the claims for which federal judicial review would be sought, however, the fair hearing procedure is wholly inadequate, and the plaintiff should be able to proceed directly to the district court under section 1983.

1. Practical Non-existence of the Administrative Remedy. Of course, if no administrative remedy exists the exhaustion doctrine is inapplicable. ${ }^{100}$ Thus, the district court would not oblige the plaintiff initially to seek relief from any federal agency, for the Department of Health, Education, and Welfare has yet to provide any formal appellate procedure for dissatisfied individual claimants. Similarly, there may be situations in which no state administrative remedy is afforded. The clearest instance is that in which the welfare recipient wishes to challenge an allegedly illegal condition upon his receipt of aidmidnight searches, for example. He will probably be unwilling or unable to risk the loss of livelihood by refusing to consent to such searches. However, unless the recipient is taken off welfare as a result of the raid itself or because of his refusal to consent, he cannot obtain any administrative relief under most state plans ;10 a fair hearing need be held only when an order directly affects the amount or existence of aid. ${ }^{111}$

Nor would the federal court require the recipient deliberately to exclude himself from aid or to wait until he had been cut off in order to open the channels to administrative review. Certainly if the police had conducted an illegal search, the victim would have a right of action under section 1983 whether or not further official action had been taken against him as a result of the findings of the search. ${ }^{112}$ Indeed, the mere existence of such a practice by the local police-or by welfare agencies-might afford an aggrieved individual standing to seek an injunction against further conduct which could

106. 42 U.S.C. $\$ 302(a)(4)$ (1964); 42 U.S.C. $\$ \$ 602(a)(4), 1202(a)(4), 1352(a)$ (4) (Supp. I, 1965); FEDERAL HANDBooK, Part IV, \& 6200 (3).

107. Federal HandBook, Part IV, \& $6200(2)$.

108. The statutory provisions cited in note 106 supra, say nothing of a time limit for hearings. The regulation in the Federal Handbook only provides that the hearing be provided proinptly. FEDERAL HANDBOOK, Part IV, \& 6200 (3) (f). The recommended time limit is 30 days. Many states comply with this, but some take 60 days.

109. See, e.g., Moore v. Illinois Cent. R.R., 312 U.S. 630, 634-35 (1941).

110. See, e.g., Ga. Manual, Part III, \& X, at 4(D). But see ArK. Manual $6220(7)$.

111. Federal statutes and regulations confine their attention to appeal from denials of aid or failures to act upon applications. See note 106 supra.

112. See Monroe v. Pape, 365 U.S. 167 (1961). 
affect his, or others', fourth amendment rights. ${ }^{113}$ Declaratory or injunctive relief is not available from the welfare agencies, and they need not, therefore, be petitioned for a remedy which they have no power to provide.

2. Futility of Pursuing the Administrative Remedy. It is generally held that where pursuit of an administrative remedy would be futile, exhaustion is not a prerequisite to federal judicial review. ${ }^{114}$ If the state welfare agency would refuse in a fair hearing to rule upon the constitutional or statutory validity of a challenged regulation, recourse to that procedure would clearly be unavailing.

Consequently, in a jurisdiction in which the agency has already held itself incompetent to consider the validity of its regulations, exhaustion clearly would not constitute a condition of review under section 1983. Such a circumstance would fall squarely within the rule laid down by the Court of Appeals for the Ninth Circuit in Koepke v. Fontecchio:

The Housing Expediter had already announced his interpretation. He later embodied it in a regulation, and he still insists upon it here. In such circumstances an attempt to secure relief by resort to the socalled administrative remedies would clearly have been futile and equity does not require the doing of a useless thing. 115

This rule has been reiterated in section 1983. suits in which the previous actions or the announced policy of the administrative agency indicated that the requested redress would be denied. ${ }^{116}$ In welfare cases, futility would probably also exist if the agency had already upheld the regulation or had regularly denied relief in nearly identical cases.

When there is no specific regulation or declaration of intent by the administrative autlority, futility may be more difficult to establish. It is true that in the only discovered decisions on the question, state welfare departments have deemed themselves powerless to rule on the legality of their own regulations in a fair hearing. ${ }^{117}$ In each case it was held that such a deter-

113. See Langford v. Gelston, 364 F.2d 197 (4th Cir. 1966).

114. See, e.g., Levers v. Anderson, 326 U.S. 219 (1945); United States v. Abilene \& So. Ry., 265 U.S. 274 (1924) ; L. JAFFe, JUdicial Control of AdMINISTRATIVE ACtIoN 446-49 (1965).

115. 177 F.2d 125, 128 (9th Cir. 1949). This statement was actually dictum in the Koepke opinion. First, the "so-called" administrative remedy appears to have been an action at law. Second, the court noted that the regulations embodying the agency's policy had "no bearing upon the issue here presented and [that] the Act provides no administrative remedy. ... Id. at 128 . However, though the decision is probably more accurately described as holding that the remedy was non-existent rather than that its pursuit was futile, the case is generally recoguized as authority for the rule that exhaustion of a futile remedy is not necessary. See, e.g., L. JAFFE, supra note 114, at 449. See also Montana Nat'l Bank v. Yellowstone County, 276 U.S. 499, 505 (1928); Waite v. Macy, 246 U.S. 606 (1918).

116. Farley v. Turner, 281 F.2d 131 (4th Cir. 1960) ; Borders v. Rippy, 247 F.2d 268 (5th Cir. 1957); School Bd. v. Allen, 240 F.2d 59, 63-64 (4th Cir. 1956), cert. denied, 353 U.S. 910 (1957).

117. In the only cases that have come to our attention which have raised, at the fair hearing, the question of the invalidity of the regulation in a formal manner, the state departments ruled that the question could not be decided in the administrative process, 
mination could properly be obtained only in a judicial forum. But a finding of futility cannot rest on the assumption that all state agencies deem themselves similarly powerless. Since HEW rules mandate a hearing procedure which will be binding upon the state agency, most states have provided that the decisions in fair hearings be made by the same persons who are authorized to promulgate regulations. ${ }^{118}$ Presumably, the power to create rules and regulations includes a power to modify or abrogate them.

One means to establish futility is to demonstrate consistent bad faith on the part of the agency. ${ }^{110}$ It is the impression of some lawyers familiar with welfare litigation that some state agencies consistently attempt to avoid confronting policy issues. ${ }^{120}$ "Individual adjustments" are frequently negotiated with persons who seem determined to challenge a given policy. While good faith avoidance of disrupting broad decisions may be wise in some cases, conscious efforts to evade general questions for the purpose of obstructing either administrative or judicial invalidation of regulations constitute actions talen in bad faith which should obviate the necessity for exhaustion. Such conduct is especially inexcusable in welfare cases in view of the inability of most welfare claimants to prosecute their individual grievances effectively. Particularly when the agency's bad faith is motivated by racial discrimination, the federal court should deem exhaustion futile and unnecessary. ${ }^{121}$

3. Section 1983 and Exhaustion. There is a growing body of judicial authority to the effect that exhaustion of administrative remedies may never be required for an action properly brought under section 1983. The genesis of this development was Monroe v. Pape, ${ }^{122}$ in which the Supreme Court held that the plaintiff was not required to pursue his state judicial remedies for an unlawful search before prosecuting a section 1983 action in the district court. Two years later, in McNeese v. Board of Education, ${ }^{123}$ the Court reiterated this notion in deciding that exhaustion of a state administrative remedy was unnecessary. The plaintiffs, Negro children, had brought suit under section 1983 to enjoin the alleged practice of segregation in an Illinois public

but would require an action in court. Memorandum of Decision, Request of Miss Dorothy Reed, Case No. 92-C-74675 (Aug. 22, 1966), Conn. State Welfare Dep't, at 2: "Attorney was advised a mandamus action was the proper procedure to contest the adequacy of agency standards." See also Decision in Regard to Appeal for Fair Hearing in the Case of Mrs. Ovelia Robinson, Newark, N.J., Case No. EC-9475 (April 4, 1966).

118. See note 57 supra.

119. Compare Covington v. Edwards, 264 F.2d 780 (4th Cir.), cert. denied, 361 U.S. 840 (1959), and Carson v. Board of Educ., 227 F.2d 789 (4th Cir. 1955), and Davis v. Arn, 199 F.2d 424 (5th Cir. 1952), with Farley v. Turner, 281 F.2d 131 (4th Cir. 1960).

120. "[New York] State department policy appears to be that of avoiding hearings and rulings on policy issues whenever possible." Memorandum from Edward V. Sparer, Director, Columbia School of Social Work, Legal Research Division, to Helmet Furth, $r e$ "Federal requirements for welfare fair hearing procedure not observed in New York," at 7. Copy on file with the Colnmbia Law Review.

121. It should be pointed out that proving bad faith may, as a practical matter, be very difficult.

122. 365 U.S. 167, 183 (1961).

123. 373 U.S. 668 (1963). 
school. The district court dismissed the action because of their failure to avail themselves of the procedure provided by the Illinois School Code whereby complaints of segregation could be taken to the Superintendent of Schools upon a petition signed by a certain number-not less than fifty-of the school district's residents. In the course of its opinion reversing the dismissal, the Supreme Court cited Monroe for the general proposition that "relief under the Civil Rights Act may not be defeated because relief was not first sought under state law which provided a remedy." ${ }^{24}$ This language on its face can be read as completely dispensing with the exhaustion requirement in any action under the Civil Rights Act. Indeed, the Courts of Appeals for both the second and fourth circuits as well as a number of district courts have so interpreted the $M c N e e s e$ decision. ${ }^{125}$ If this view prevails, the availability of a state fair hearing will be no obstacle to the welfare claimant asserting a federal constitutional right under section 1983.

Some courts, however, have construed McNeese more narrowly, ${ }^{126}$ and with good reason. The Supreme Court's opinion focused primarily upon the inadequacy of the Illinois administrative remedy, emphasizing that the requirement of fifty signatures afforded little opportunity for the vindieation of individual rights and that the Superintendent's remedial powers, even if he found unlawful segregation, were insufficient to give prompt and effective relief. ${ }^{127}$ Thus, the Court did not throw out the exhaustion doctrine altogether; rather its precise holding was that " $[w]$ hen federal rights are subject to such tenuous protection, prior resort to a state proceeding is not necessary." ${ }^{28}$

Even if McNeese did not render exhaustion a dead issue in all eases, it nevertheless did substantially mitigate the requirement for section 1983 cases. Moreover, it indicated that the courts should closely scrutinize the adequacy of the administrative relief. Under such rigorous standards a state fair hearing procedure may be found insufficient unless it provides a clear remedy not only for the denial of aid but also for other challenges to the validity of the welfare regulations. It must be remembered, however, that the experience to date of attacking regulations in fair hearings is very limited. ${ }^{129}$ To a large extent, the evolution of the relaxed exhaustion requirement in the school desegregation

124. Id. at 671 .

125. See, e.g., Rivers v. Royster, 360 F.2d 592 (4th Cir. 1966) ; Powell v. Workmen's Compensation Bd., 327 F.2d 131 (2d Cir. 1964); Clarke v. Redeker, 259 F. Supp. 117 (S.D. Iowa 1966).

Pa. 1965).

126. Sec, e.g., United States ex rel. Wakeley v. Pennsylvania, 247 F. Supp. 7 (E.D.

127. The Superintendent has the power only to inform the state attorney general of the discriminatory practice. The attorney general must then bring suit to rectify the situation. 373 U.S. at 670 .

128. 373 U.S. at 676.

129. An effective challenge to the substance of a regulation at a fair hearing, of necessity, would involve representation by competent counsel. Only recently has there been anything even remotely resembling a systematic effort to provide legal services to the poor for areas of civil law. 
cases was the result of nearly a decade of experience and judicial impatience with a particular type of local agency. ${ }^{130}$ Certainly, it is to be hoped that the states will evolve clear and expeditious administrative procedures for adjudicating the validity of regulations as the challenges to presently constituted welfare programs increase. ${ }^{131}$ If such remedies are developed, there will be less compelling reason to excuse exhaustion before judicial review. However, judicial tolerance and the presumption of good faith on the part of the agencies need not endure for a decade if positive efforts to enlarge or clarify present administrative remedies are not made. The condition of the welfare claimantuncontestably qualified on the basis of need but excluded by operation of an illegal rule-is sufficiently precarious to warrant zealous federal enforcement of often fundamental constitutional rights. The passage of time itself creates injury grcat enough to warrant judicial scrutiny of the adequacy of available administrative remedies-a scrutiny at least as close as that in the school desegregation cases.

\section{Hearings Before a Three-Judge District Court}

Many welfare suits under section 1983 probably will have to be heard and determined by statutory three-judge federal district courts pursuant to 28 U.S.C. $\$ 2281$, which provides that only such courts are empowered to restrain enforcement of state laws on grounds of unconstitutionality. ${ }^{\mathbf{1 3 2}}$ For welfare claimants the three-judge court is a particularly desirable and effective method of judicial review, especially in the initial test cases. Direct appeal of the decision of the statutory court to the Supreme Court is afforded by statute, ${ }^{133}$ - a more expeditious route to the top of the federal judiciary. Moreover, the quality of the district court will often be improved, ${ }^{134}$ particularly in the South,

130. The decade of frustration with the manifold attempts by both local communities and states to avoid desegregation is, perhaps, epitomized by Griffin v. County School Bd. 377 U.S. 218 (1964), where, when the case reached the Supreme Court, public schools had been inoperative for more than five years. Confronted with situations like that in Prince Edward County, it is no wonder that the Supreme Court ultimately had to ensure access to the federal courts as quickly as possible.

131. In New York, a systematic effort is being made to make legal aid available to welfare challengers. Law students, working through the Law Students' Civil Rights Research Council (LSCRRC) are cooperating with attorneys who are handling welfare cases.

132. 28 U.S.C. \& 2281 (1964) reads :

Any interlocutory or permanent injunction restraining the enforcement, operation or execution of any State statute by restraining the action of any officer of such State in the enforcement or execution of such statute or of an order made by an administrative board or commission acting under State statutes, shall not be granted by any district court or judge thereof upon the ground of the unconstitutionality of such statute unless the application therefor is heard and determined

by a district court of three judges under section 2284 of this title.

Of course, the decision whether or not a three-judge court will be convened does not rest with the plaintiff or the discretion of the court; its appropriateness depends entirely upon the existence of the statutory conditions.

133. 28 U.S.C. \& 1253 (1964).

134. There are some federal district judges in the South who civil rights lawyers feel cannot be relied upon for unbiased justice. In those districts, the addition of one judge from the relatively good Fifth Circuit and of one other district judge will often turn a bad 
because at least one circuit judge must sit on the court. ${ }^{135}$ Finally, the decision of a three-judge court, even if not reviewed by the Supreme Court, is likely to be accorded greater weight than the holding of a single district judge.

1. Availability of Three-Judge Court to Review Welfare Regulations. There is some doubt whether a three-judge court can be convened when the constitutional attack is focused upon the state administrative regulations, but not upon the enabling statute. The question was apparently answered decisively in the affirmative by the Supreme Court's decision in Oklahoma Gas Co. $v$. Russell. ${ }^{136}$ In that case it was argued that although section 266 of the Judicial Code (the predecessor of section 2281) required a three-judge court for issuance of injunctions against "enforcement ... of an order made by an administrative board," such a court was needed only when the injunction was based upon the "unconstitutionality of such [authorizing] statute. . .."137 The Court flatly rejected this construction and held that the statutory court was necessary despite the plaintiff's failure to attack any state statute. As the Supreme Court recognized, the legislative intention of the section was to prevent a single judge from interfering with state pronouncements which are of binding effect and general application. ${ }^{138}$ Since welfare regulations clearly fit this description, constitutional challenges to their validity are precisely the type of action to which the statute is addressed.139

Nevertheless, in Sweeney v. State Board of Public Assistance, ${ }^{140}$ the only welfare case in which this question has been raised, the court reached a contrary result. The plaintiffs sought an injunction in federal district court against enforcement of a regnlation of the Pennsylvania Department of Public Assistance on the ground that it violated the fourteenth amendment. The court held that to invoke a three-judge court would be improper when the constitutionality of the regulation, but not of the statute pursuant to which it was promulgated, was put into question. The Court did not mention Oklahoma Gas Co. v. Russell. Instead, it relied upon Ex Parte Bransford, ${ }^{141}$ a case in which the Supreme Court, ignoring Oklahoma, had held that a three-judge court was not necessary to hear a constitutional challenge to an individual

court into an excellent, three-judge court. See generally L. Friedman, The Federal Courts of the South: Judge Bryan Simpson and His Reluctant Brethren, in SoUTHERN JUSTICE 187 (Friedman ed. 1963).

135. 28 U.S.C. \& 2284(1) (1964).

136. 261 U.S. 290 (1923).

137. 28 U.S.C. \& 2281 (1964).

138. See AFL v. Watson, 327 U.S. 582, 592 (1946).

139. In $A F L v$. Watson, the Supreme Court stated: "In our view the word 'statute' in $\S 266$ [now 28 U.S.C. $\& 2281$ ] is a compendious summary of various enactments, by whatever method they may be adopted, to which a State gives her sanction and is at least sufficiently inclusive to embrace constitutional provisions." 327 U.S. 582, 592-93 (1946). Of course, Watson stands only for the proposition that state constitutional provisions are covered by $\$ 2281$. However, in the light of Oklahoma Gas Co. v. Russell, the dictum may be read to cover regulations of general applicability.

140. 36 F. Supp. 973 (M.D. Pa.), aff'd per curiam, 119 F.2d 1023 (3d Cir.), cert. deried, 314 U.S. 611 (1941).

141. 310 U.S. 354 (1940). 
tax assessment when the statute itself was not impugned. The authority was not on point. Tax assessments had previously been held by the Supreme Court to lack the general binding applicability necessary to bring them within the ambit of section 2281.142 Furthermore, factual determinations such as the fixing of individual rates and taxes have generally not been considered "orders" within the meaning of this statute. ${ }^{143}$

A recent district court decision in $M c W o o d$ Corp. v. State Corporation Commission ${ }^{\mathbf{1 4 4}}$ may serve to clarify the circumstances under which a threejudge court must be convened to determine the constitutionality of administrative regulations. The issue in that case was whether section 2281 applied in a suit to enjoin the state commission's cease-and-desist order directed to the plaintiff; the validity of the statute authorizing the commission's conduct was not in issue. The court was clearly troubled by the potential inconsistency between the Oklahoma and Bransford decisions and held section 2281 inapplicable on narrow grounds rather than under a broad rule requiring, in all cases, a constitutional attack upon a statute. Thus, the court stated that "an agency determination which is primarily a finding of fact"145 does not fall within the statute; rather the "complainant must seek to forestall the demands of some general state policy." 146 Clearly the welfare claimant's section 1983 suit satisfies both of these criteria. Welfare regulations are neither factual determinations nor individual exclusions from aid. On the contrary, they embody the state-wide policy of the welfare commission, whose authority derives from the most unspecific of enabling statutes. ${ }^{147}$

2. Scope of the Court's Jurisdiction. If a statutory three-judge court is convened to determine the constitutionality of the welfare regulation, will it also consider challenges to the regulation which are based on a federal statute, a federal regulation, or a state statute? In Florida Lime \& Avocado Growers, Inc. v. Jacobsen, ${ }^{148}$ the Supreme Court held that the assertion of non-constitutional claims in conjunction with a nonfrivolous constitutional attack did not

142. Ex parte Williams, 277 U.S. 267 (1928).

143. See id. See also Marshall v. Sawyer, 301 F.2d 639 (9th Cir. 1962) (holding a three-judge court unnecessary where the administrative action is a particularized finding of fact).

144. 237 F. Supp. 963 (D.N.M. 1965).

145. Id. at 965 .

146. Id. See also Phillips v. United States, 312 U.S. 246 (1941).

147. Assuming a non-frivolous claim by the plaintiff that a state regulation or statute does violate the United States Constitution, the only factor which might make unnecessary the convening of a three-judge court would be that "prior decisions make frivolous any claim that a state statute on its face is not unconstitutional." See, e.g., Bailey v. Patterson, 369 U.S. 31,33 (1962) (question presented was whether a state, by statute, could require the use of segregated facilities in interstate commerce); Turner v. City of Memphis, 369 U.S. 350 (1962) (same). This principle, however, assumes, first, that the Supreme Court has ruled on the question presented and, second, that the particular state statute in question on its face violates precisely the principle decided by the Court. Clearly, absent a wholly obvious atteinpt to bar Negroes from partaking of welfare benefits, the welfare regulations do not yet present such patent unconstitutionality.

148. 362 U.S. 73 (1960). 
remove the case from the operation of section 2281 , and that the three-judge court could adjudicate all the claims. In the recent case of Hobson $v$. Hansen, ${ }^{140}$ however, Chief Judge Bazelon of the District of Columbia Circuit limited the broad language of the Florida Lime opinion. Where the various counts in a complaint arise from different actions of the defendants and involve essentially different factual questions, a three-judge court may hear only those claims which in fact raise constitutional issues. ${ }^{150}$ Those non-constitutional claims which are not intimately related to claims properly encompassed by section 2281 must be adjudicated separately by a single-judge court.

Most challenges to welfare regulations will clearly be ruled by Florida Lime. Usually it will be claimed that a certain regulation violates both the Constitution and the federal statute or HEW rules. However, there may be cases where a particular part of a regulation-the no-supplementation provision of an employable mother rule, for example ${ }^{151}$-will be challenged as unconstitutional, while another practice-such as refusal of an official to accept applications-will be alleged to contravene the federal statute. ${ }^{152}$ In such a case the distinct legal and factual nature of the claims, though not barring joinder under rule $18(\mathrm{a})$ of the federal rules, might, under Hobson, prevent the three-judge court from hearing the purely statutory claim.

\section{Non-Constitutional Challenges to State Welfare Practices}

Section 1983 creates a cause of action for deprivations not only of rights guaranteed by the Constitution, but also of "any rights, privileges, or immunities secured by the ... laws" of the United States. ${ }^{153}$ A welfare claimant might, then, bring an action against responsible state officials alleging that a regulation or prevalent administrative practice contravened the Social Security Act or mandatory federal regulations. The problems of abstention and exhaustion will, with minor exceptions, ${ }^{154}$ be the same as those confronting

149. 256 F. Supp. 18 (D.C. Cir. 1966).

150. Id. at 20 .

151. See note 39 supra and accompanying text.

152. Clearly, such a joinder of claims would be permissible under FED. R. CIV. P. 18(a). The statutory provisions involved are 42 U.S.C. $\$ \S 302(a)(9), 602(a)(9)$, 1202 (a) (9), 1352 (a) (9) (1964).

153. 42 U.S.C. \& $1983(1964)$.

154. To the extent that the reasoning behind a relaxed exhaustion doctrine for school desegregation eases is applicable to the welfare situation, the case for relaxing exhaustion requirements for the claimant alleging simply a statutory violation may be somewhat weaker than the case when a substantial constitutional question is present. Presumably, if Congress creates the right, Congress may limit, expressly or by implication, enforcement of the right by conditioning it upon following a prescribed procedure, whether judicial or administrative. Thus, Congress inay, in some cases, explicitly provide that a complex system of adininistrative remedies be followed. In the welfare situation, the only inference of this nature arises from the fact that Congress apparently left the question of process of review primarily to the states. When substantial constitutional rights are asserted, however, which are of such a nature that delay causes irreparable injury, the McNeese doctrine would presumably apply. Some welfare cases fit this inold. The claimant is forced to choose between loss of a right which is inherently non-coinpensable (submission to illegal search and seizure) and loss of livelihood. However, if the nature of the relaxed 
the plaintiff who asserts a constitutional claim. However, there are additional difficulties in bringing an action based upon a federal statute or regulation. The claimant must establish that the Social Security Act or HEW regulations bestow "rights, privileges, or immunities" upon persons seeking welfare. And even assuming that a right exists within the meaning of section 1983, there may be no basis for the jurisdiction of the district court, since the scope of the jurisdictional companion statute to section 1983, 28 U.S.C. $\S 1343(3)$, is arguably not co-extensive with the latter section.

\section{A. Rights, Privileges, and Immunities}

The Social Security Act does not confer upon anyone the "right" to welfare. No state is obligated to participate in the federal program or to provide state aid of any kind. ${ }^{155}$ The act ean, however, be deemed to create a right of a less absolute nature: the right, in any state which has elected to benefit from the federal program, to be considered for public assistance in accordance with the criteria, and subject to the safeguards, required by the act. Courts have been zealous in protecting such rights, even when attached to the receipt of "benefits" or "gratuities."156 The welfare claimant in a section 1983 action seeks only the same protection. He asserts no unqualified right to a welfare check, but rather claims that he is entitled to have his claim considered in a manner which conforms to all statutorily mandated criteria and safeguards. The "rights, privileges, and immunities" language of section 1983 is deliberately broad, and a properly expansive construction would include the right to treatment by state welfare officials consistent with the federal statute.

In determining whether a challenged state practice is inconsistent with the federal statute, a court should look to federal administrative rulings, even if no violation of a specific provision of the Social Security Act is apparent. An HEW rule represents a statutory interpretation by the federal agency specifically authorized by Congress to promulgate regulations to define and

McNeese doctrine arises from the nature of and experience with local school boards and the pressing urgency of the injury, then the welfare cases would fit the mold whether or not the violation alleged is of a constitutional dimension.

155. See notes 10,12 sipra.

156. Thus, in Freeman v. Brown, 342 F.2d 205 (5th Cir, 1965), no claim was made that the plaintiff's' tobacco should necessarily be treated in a certain way for purposes of allotments, but only that they had a right to a decision made by the Secretary of Agriculture in conformity with the statutory requirements. Similarly, in Gonzalez v. Freeman, 334 F.2d 570 (D.C. Cir. 1964), no right was asserted to contract with the Government, but only to be accorded procedural fairness in the process of selecting government contractors. Nor in Harmon v. Brucker, 355 U.S. 579 (1958), was any right to an honorable discharge alleged. Nevertheless, the use of impermissible criteria by the Secretary of the Army in determining whether a discharge should be honorable was held enough, even in this sensitive area of national defense, to justify interference by a court.

157. See, e.g., NLRB v. Hearst Publications, Inc., 322 U.S. 111 (1944); Gray v. Powell, 314 U.S. 402 (1941). 
effectuate the statutory goals. As such, it is entitled to the same presumption of correctness ${ }^{157}$ and force of law $^{158}$ as is any other administrative action.

\section{B. Jurisdiction of the District Court}

Assuming that the welfare claimant has a cause of action under section 1983 based on the state's violation of the federal statute or regulations, he must further establish the jurisdiction of the district court. His problem is to bring the suit within a jurisdictional statute which does not require the amount in controversy of 28 U.S.C. $\$ 1331$. Individual welfare claims, however computed, ${ }^{159}$ will rarely exceed $\$ 10,000$. And it is unlikely that the plaintiffs in a class action would be permitted to aggregate their clains. Under the previous version of rule 23 of the Federal Rules of Civil Procedure, aggregation was allowed only in a "true"160 class action, not in a "hybrid"161 or "spurious"162 class action, ${ }^{163}$ and a suit by welfare claimants would undoubtedly have fallen within one of the latter categories. ${ }^{164}$ This result does not seem to have been altered by the recently amended version of rule $23,{ }^{165}$ for the rationale upon which aggregation has traditionally been denied-the severability of the individual claims-is apparently unaffected by the otherwise substantial changes in rule 23.

If jurisdiction can be obtained under 28 U.S.C. $\S 1343(3),{ }^{166}$ however, there is no requirement of an amount in controversy. ${ }^{167}$ The language of this

158. See, e.g., United States v. Mersky, 361 U.S. 431 (1960) ; Columbia Broadcasting System v. United States, 316 U.S. 407 (1942).

159. Assuming one did want to determine the amount in controversy when dealing with a welfare claim, the computation would be difficult. There is no adequate way of determining for what length of time a given individual would remain eligible for payments since eligibility may legitimately depend upon factors likely to change at any time-from the health of the recipient to the general economic prosperity of a geographical area.

160. FED. R. Crv. P. 23 (a) (1), 308 U.S. 689 (1939).

161. FED. R. CIv. P. 23 (a) (2), 308 U.S. 689 (1939).

162. FEd. R. CIV. P. 23(a) (3), 308 U.S. 689 (1939).

163. See, e.g., Clark v. Paul Gray, Inc., 306 U.S. 583 (1939); Fuller v. Volk, 351 F.2d 323 (3d Cir, 1965) (treating the law as well settled that aggregation is allowed only in true class actions). But see Brotherhood of R.R. Trainmen v. Templeton, 181 .F2d 527 (8th Cir.), cert. denied, 340 U.S. 823 (1950) (allowing aggregation in a spurious class action).

164. The rights of the welfare claimants would be "several."

165. Welfare class actions would fall under new rule $23(\mathrm{~b})(2)$ :

The party opposing the class has acted or refused to act on grounds generally applicable to the class, thereby making appropriate final injunctive relief or corresponding declaratory relief with respect to the class as a whole. . . .

166. The district courts shall have original jurisdiction of any civil action authorized by law to be commenced by any person:

(3) To redress the deprivation, under color of any State law, statute, ordinance, regulation, custom or usage, of any right, privilege or immunity secured by the Constitution of the United States or by any Act of Congress providing for equal rights of citizens or of all persons within the jurisdiction of the United States. ... .

28 U.S.C. \& 1343 (1964).

167. "As we held in Hague v. C.I.O., ... the district courts of the United States are given jurisdiction by 28 U.S.C. $\$ 41$ (14) [now 28 U.S.C. $\$ 1343$ (1964)] over suits brought 
section is parallel to that of section 1983 with one major exception. ${ }^{108}$ While section 1983 creates a cause of action for deprivation of rights secured by all "laws" of the United States, section 1343(3) gives the district courts jurisdiction of suits to redress only deprivations of rights secured by laws "providing for equal rights." (Emphasis added.) Since the Social Security Act is hardly a law providing for equal rights, the district court would appear to be without jurisdiction of statutory welfare claims under section 1983.

In most section 1983 cases, however, the dilemma created by the discrepancy in language can be avoided by finding other sources of federal jurisdiction. ${ }^{162}$ Even if the requisite amount in controversy under 28 U.S.C. $\S 1331$ is not present, the district court may have jurisdiction on the ground that the right infringed is guaranteed by an act which regulates commerce ${ }^{170}$ or by a statute providing for internal revenue. ${ }^{171}$ The public assistance statutes, however, are certainly not acts regulating commerce. Nor are they revenue acts; while sections of the Social Security Act relating to social security insurance have been upheld under the power of Congress to provide for internal revenue, the welfare provisions were not at issue in those decisions. ${ }^{172}$ Federal jurisdiction of non-constitutional challenges to welfare regulations, then, will depend upon the construction of section 1343(3).

The reason for the variance in language between the two statutes is not clear. In the Revised Statutes of 1875, section 1979-the precursor of section 1983-and section 563(12) - the provision for civil rights jurisdiction in the district courts-were identical in scope. Section 563(12) contained no language limiting the word "laws" to those providing for equal rights. However, the provision which gave the circuit courts of that time original jurisdiction of civil rights suits, section $629(16)$, did restrict the scope of the grant to actions for deprivations of rights under "laws providing for equal rights."

under the Civil Rights Act [42 U.S.C. § 1983] without the allegation or proof of any jurisdictional amount." Douglas v. City of Jeannette, 319 U.S. 157, 161 (1943).

168. There is a second minor difference in language in that $\$ 1343(3)$ appears to apply by its language only to deprivation under color of state authority, while $\S 1983$ applies to that of states and territories.

169. A vast number of cases fall under the provisions of 28 U.S.C. $\S 1337$ (1964) providing for jurisdiction in cases arising under acts of Congress regulating commerce. The issue of whether the difference in language would ever preclude jurisdiction when such an alternative source is not present is explicitly recognized as undecided. See Pugach v. Dollinger, 277 F.2d 739 (2d Cir. 1960), aff'd per curiam, 365 U.S. 458 (1961). In P1tgach, the issue was whether a federal court had jurisdiction to enjoin a state court prosecutor from using evidence obtained through a violation of the Federal Communications Act. Since the federal statute involved is one regulating commerce, the problem of whether jurisdiction would have been present under 28 U.S.C. \& 1343(3) (1964), since the act does not provide for equal rights, did not have to be decided.

170. 28 U.S.C. $\$ 1337$ (1964); see Pugach v. Dollinger, 277 F.2d 739 (2d Cir. 1960), aff'd per curiam, 365 U.S. 458 (1961).

171. 28 U.S.C. $\$ 1340$ (1964).

172. See Helvering v. Davis, 301 U.S. 619 (1937) ; Steward Mach. Co. v. Davis, 301 U.S. 548, 598 (1937).

173. REv. STAT. \& 1979 (1875), 42 U.S.C. \& 1983 (1964), is derived from the third Civil Rights Act of the Reconstruction period-1871. The jurisdictional sections are of earlier origins and appear to have been intended to establish jurisdiction for the 1866 
In the 1910 revision of the Judiciary Code, the two jurisdictional provisions were merged, original jurisdiction remaining only in the district courts. ${ }^{174}$ The new section retained the limitation found in the previous circuit court provision. No satisfactory explanation can be given for the retention of this qualifying phrase; it may well have been merely a drafting oversight during a major revision and codification. Certainly there is no evidence that Congress intended to diminish the prior jurisdiction of the district court. Indeed, some of the brief legislative history suggests precisely the contrary-that the sole purpose was to remove any original civil rights jurisdiction from the circuit courts and to vest in the district court whatever jurisdiction had previously existed in the two courts. ${ }^{175}$

The difference in language caused no immediate concern, for some courts were interpreting section 1983 so narrowly that many deprivations of constitutional rights were held not to give rise to a cause of action. ${ }^{176}$ However, in 1947, the issue of the scope of the district court's jurisdiction over statutory claims under section 1983 was raised before the Court of Appeals for the Second Circuit in Bomar v. Keyes. ${ }^{177}$ Judge Learned Hand held that the court had jurisdiction of a suit by a substitute teacher against school officials who had fired her, allegedly because she had been absent for four days on federal jury duty. No constitutional right to jury duty had been asserted. ${ }^{178}$ Rather, the decision rested on the ground that the federal jury statute created a "privilege" which was subject to the protection of section 1983. 179 Although the federal statute was clearly not a law providing for equal rights, Judge

civil rights statutes. Note, The Proper Scope of the Civil Rights Acts, 66 Harv. L. Rev. 1285, 1291-93 (1953).

174. S. REP. No. 388, 61st Cong., 2d Sess., pt. 1, at 15 (1910).

175. "This paragraph [paragraph 14 of $\$ 24$ of title II of the Senate Bill] merges the jurisdiction now vested in the district courts by paragraph 12 of section 563, and in the circuit courts by paragraph 16 of section 629 , and vests it in the district courts." Id.

176. Some courts seemed to be saying that $\$ 1983$ was available only for denials of due process, and not for deprivations of equal protection. See, e.g., Ortega v. Ragen, 216 F.2d 561 (7th Cir. 1954) (alternative holding), cert. denied, 349 U.S. 940 (1955); McShane v. Moldovan, 172 F.2d 1016, 1018 n.2 (6th Cir. 1949) (dictum). Other courts were giving a very narrow interpretation to the phrase "under color of ... law." See, e.g., Monroe v. Pape, 272 F.2d 365 (7th Cir. 1959), rev'd, 365 U.S. 167 (1961) ; Stift v. Lynch, 267 F.2d 237 (7th Cir. 1959); Miles v. Armstrong, 207 F.2d 284, 286 (7th Cir. 1953). See generally Comment, The Civil Rights Acts and Mr. Monroe, 49 CALIF. L. REv. 145 (1961); Note, The Proper Scope of the Civil Rights Acts, supra note 173; Note, Section 1983: A Civil Remedy for the Protection of Federal Rights, 39 N.Y.U.L.REv. 839 (1964).

177. 162 F.2d 136 (2d Cir.), cert. denied, 332 U.S. 825 (1947); see Note, The Proper Scope of the Civil Rights Acts, supra note 173, at 1291-93.

178. The distinction must be made between the constitutional right to be tried by a jury from which no class has been discriminatorily excluded [e.g., Hernandez v. Texas, 347 U.S. 475 (1954) ; Snith v. Texas, 311 U.S. 128 (1940)] and the "right" or "privilege" to be on a jury. Whether this latter is, in fact, a right, is open to doubt, but several recent cases have held that purposeful discrimination against persons in keeping them from jury duty is a violation of their "rights, privileges, or immunities" within the meaning of 42 U.S.C. \& 1983. See, e.g., Billingsley v. Clayton, 359 F.2d 13 (5th Cir.), cert. deried, 87 S. Ct. 92 (1966); White v. Crook, 251 F. Supp. 401 (M.D. Ala. 1966) (per curiam); Mitchell v. Johnson, 250 F. Supp. 117 (M.D. Ala. 1966).

179. 162 F.2d at 139. 
Hand apparently did not perceive a potential obstacle to juriscliction in the limiting language of section 1343(3). Indeed, section 1343(3) was not even mentioned in the opinion, and it has therefore been suggested that he may have been proceeding on the assumption that section 1983 itself conferred jurisdiction on the district court. ${ }^{180}$ Alternatively, Judge Hand may have proceeded on the assumption that jurisdiction under 1343(3) was coextensive with the cause of action created by section 1983 despite the slight difference in language. Supreme Court decisions had apparently laid down the broad rule that section $1343(3)$ conferred jurisdiction over all suits properly brought under section 1983 irrespective of the amount in controversy. ${ }^{181}$ Since those cases had involved constitutional rather than statutory claims, however, the difference between the language of the two sections was irrelevant.

The result in Bomar is defensible, ${ }^{182}$ even though it is difficult to justify under rigid notions of statutory construction. Under a contrary interpretation, a plaintiff with a valid non-constitutional cause of action under section 1983 would be barred from obtaining federal relief. Yet, the purpose of section 1983 is to provide a federal judicial remedy for deprivations of rights under color of state law, regardless of the existence of a state judicial remedy. ${ }^{183} \mathrm{~A}$ narrow construction of the jurisdictional statute would defeat the congressional purpose to create a cause of action which need not be brought in the state courts.

The welfare claimant's suit, in any event, should rarely raise this question under section $1343(3)$. In most instances, statutory arguments will not be presented alone. The same regulation will be challenged on both constitu-

180. See Note, The Proper Scope of the Civil Rights Acts, sipra note 173, at 1292. See also Comment, The Civil Rights Acts and Mr. Monroe, supra note 176, at 148-51. Indeed, such a conclusion is fortified by his identification of the issue as "whether the district court had jurisdiction under the Civil Rights Act." 162 F.2d at 138 (emphasis added).

181. See Douglas v. City of Jeannette, 319 U.S. 157 (1943).

182. The argument is powerful that the Reconstruction Congress intended simply to establish jurisdiction in the federal courts whenever there was a cause of action under the civil rights statutes. "This responsibility [to shape American federalism] forbids winking away the plain nationalizing purposes of the Reconstruction legislation, even on the firm conviction-which the Supreme Court has sometimes not quite managed to conceal-that bad Tad Stevens and his rads were a bit of a transient aberration not to be taken seriously." A. Amsterdam, Criminal Prosecutions Affecting Federally Guarantecd Civil Rights: Federal Removal and Habeas Corpus Jurisdiction to Abort State Court Trial, 113 U. PA. L. Rev. 793, 830 (1965). This effect could be given to the jurisdictional statute by simply stating that 42 U.S.C. $\$ 1983$ is the statute providing for equal rights, par excellence, and that whenever a cause of action exists under that statute, there is a deprivation of a right, privilege, or immunity secured by the Constitution (amend. XIV), and by a law providing for equal rights ( $\$ 1983$ ). This question has been adjudicated in a somewhat different guise. In New York v. Galamison, $342 \mathrm{~F} .2 \mathrm{~d} 255$ (2d Cir.), cert. dettied, 380 U.S. 977 (1965), the Second Circuit decided that for purposes of the removal statute [28 U.S.C. \& $1443(2)$ (1964)] \& 1983 was not a statute providing for equal rights. This decision was forcefully opposed in the dissent by Judge Marshall: "The mere fact that $\S 1983$ is 'coextensive with the whole reach of the Constitution' does not preclude the possibility that it is a 'law providing for equal rights' and much less that it could have been viewed as such by the 1875 legislators and revisers." 342 F.2d at 281 n.7. The position of the majority is given trenchant criticism in A. Amsterdam, sipra at 864-74.

183. See, e.g., Monroe v. Pape, 365 U.S. 167 (1961). 
tional and statutory grounds; under the doctrine of pendent jurisdiction, adjudication of the statutory claim will clearly he within the power of the court. ${ }^{184}$ The mere fact that the constitutional claim fails on the merits will not destroy pendent jurisdiction of the statutory claim, ${ }^{185}$ for only if the constitutional claim is frivolous will the court refuse to hear the statutory claim without an independent source of jurisdiction. ${ }^{186}$

\section{Smith v. Board of Commissioners: Initial Judicial Resistance}

Smith v. Board of Commissioners ${ }^{187}$ is the only action by welfare claimants under section 1983 which has reached final adjudication in the federal courts. Unfortunately, the hostile and peremptory treatment accorded the claim in that case may also be adopted by other federal judges confronted with so unfamiliar a suit. The brief opinion provides a panorama of the objections which will be aligned against the welfare claimant; however, close examination of the court's grounds for dismissal reveals each to be untenable.

Seeking declaratory and injunctive relief from alleged unconstitutional investigatory practices-including. midnight searches-mothers of children receiving assistance brought an action under section 1983 against the Board of Commissioners of the District of Columbia, the responsible welfare officials, and several named investigators. On defendant's motion for summary judgment, District Judge Holtzoff dismissed the complaint. The court apparently based its decision on five alternative grounds. The first was that the district court had no jurisdiction over any suit dealing with the "internal administration of this agency or any other government department."188 Entirely overlooked was the basic consideration that when officers of a government agency engage in searches, snooping, and surveillance of an individual, their actions cease to be "internal administration" and must be measured against constitutional standards.

The court's next postulate was that an agency disbursing grants and "gratuities" such as welfare has absolute discretion, precluding any judicial review. ${ }^{180}$ For the assertion of this immutable truth, no citation to authority from statute or case law was deemed necessary. Yet, neither the legislative history of the Social Security Act nor the decisions of many state courts

184. See genterally Note, The Evolution and Seope of the Doctrine of Pendent Jurisdiction in the Federal Courts, 62 CoLUar. L. REv. 1018 (1962). If the federal court will not assume original jurisdiction over the welfare claim under $\$ 1343(3)$, assuming the claim to present a cause of action, it would become a valid state claim, and the state courts would be required to enforce the federal right. Testa v. Katt, 330 U.S. 386 (1947); Mondou v. New York, N.F. \& H.R.R., 223 U.S. I (1911).

185. Hurn v. Oursler, 289 U.S. 238 (1933).

186. Levering \& Garrigues Co. v. Morrin, 289 U.S. 103 (1933).

187. 259 F. Supp. 423 (D.D.C. 1966).

188. Id. at 424 .

189. The problem of discretion, as it relates to the discretion of the federal administrator, is treated in detail at notes $236-43$ infra and accompanying text. 
during the thirty years of categorical assistance support such a view. Far from being a generally accepted principle, the principle of non-reviewability in such circumstances is disfavored; even where Congress has seen fit to preclude review by the most direct command, the courts have still recognized that the agency's discretion, although broad, is not absolute and may be subjected to judicial scrutiny. ${ }^{190}$ The Supreme Court has said that "generally, judicial review is available to one who has been injured by an act of a government official which is in excess of his express or implied powers."101 The district court in Smith identified no factor in this case which would remove it from the operation of such a presumption.

The third point is particularly inapposite. Citing Massachusetts $v$. Mellon, ${ }^{192}$ the court stated that an individual cannot "maintain an action to enjoin the day-to-day administration of government functions or the use of government funds." ${ }^{193}$ Even assuming some validity to this rule of law as stated, it bears no perceivable relevance to the Smith case. Frothingham v. Mellon ${ }^{194}$ dealt with an individual's standing to challenge government expenditures by what amounted to a taxpayer's suit; in Sinith the plaintiffs' posture was not that of taxpayers, but of persons who had suffered particular deprivations of rights by focused government action. ${ }^{195}$

The court further held that the injunctive relief requested against the defendants, their agents and successors and all persons acting in concert with them, restraining them from entering the dwellings of plaintiffs and others so situated without a search warrant or the freely given consent of the occupant, could not be granted because equity acts "in personam" and will not enjoin large numbers of unnamed defendants. However, that principle can hardly support the court's judgment in its entirety. At least two investigators were named as defendants, and this reasoning could not have led the court to deny the requested relief as to the agencies and the named investigators.

Finally, the decision rests on the plaintiffs' failure to complain of the excesses of the particular investigators to their superiors-that they failed to exhaust their administrative remedies. However, this conclusion ignores the direct allegation in the complaint that the investigators acted "in concert and participation with, under the orders, direction, control and supervision of,

190. See, e.g., Harmon v. Brucker, 355 U.S. 579 (1958) ; Estep v. United States, 327 U.S. 114 (1946). While Estep involved a defense to a criminal prosecution, Harmont was a petition for review. Review was granted despite the fact that the decision of the Secretary of the Army was designated "final" by Congress.

191. Harmon v. Brucker, 355 U.S. 579, $581-82$ (1958).

192. 262 U.S. 447 (1923).

193. 259 F. Supp. at 424 .

194. Apparently the court meant to refer to Frothingham, decided with Massachusetts v. Mellon; the latter dealt only with the issue of state standing to challenge a federal statute.

195. Plaintiffs' complaint in Smith was read into the Congressional Record by Senator Robert Byrd of West Virginia. See 112 CoNc. Rec. 27335 (daily ed. Oct. 21, 1966). 
and pursuant to practices and procedures established by defendants named herein ...." 198 Since a ruling on a motion for summary judgment pursuant to rule 56 of the Federal Rules of Civil Procedure implies that there is no "genuine issue as to any material fact," allegations of the plaintiffs must be assumed true; yet the alleged state of facts would excuse the plaintiffs from failing to exhaust administrative remedies which were clearly futile.

\section{Judicial Review of HEW Conformity Decisions}

The obligations of the Secretary of Health, Education, and Welfare under the categorical assistance titles of the Social Security Act ${ }^{197}$ are confined to determining whether a state plan conforms to mandatory federal requirements and approving or disapproving the subsequent denial of federal funds. Although the act does not provide for periodic review of state programs or for the hearing of individual complaints, the Secretary must cut off funds to an initially approved state program when violations of federal law later come to his attention. ${ }^{198}$

Nevertheless, the only specific statutory provision for judicial review is the one which permits a state dissatisfied with the Secretary's determination of non-conformity to petition for review in a United States Court of Appeals. ${ }^{190}$ If a state plan is improperly approved by the Secretary, the state would clearly have no reason to seek judicial review. Only those injured or potentially injured by the failure of the Secretary to exact conformity with federal law would be interested in having approval witheld or revoked. The welfare claimant is aptly suited to perform this role; he will often desire to proceed not only against the responsible state officials, but also against the Secretary of Health, Education, and Welfare, particularly when a state plan is riddled with abuses of many sorts. Indeed, in order to obtain effective relief it may, in many instances, be necessary to join the federal administrator as a defendant. For example, one defense available to the state agency will be that the Secretary's approval of the plan indicates that the challenged regulation is not inconsistent with federal requirements-an argument which may have considerable weight if the regulation is of a type which exists in many states. In this situation the only truly feasible or effective remedy would be a judicial decree directed against the Department of Health, Education, and Welfare.

The action for review of the Secretary's conformity finding would take the form of a petition under section 10 (b) of the Administrative Procedure

196. $I d$.

197. See notes 5-8 supra and accompanying text. 1965).

198. 42 US.C. $8 \S 304,604,1204,1354$ (1964). See also 42 U.S.C. $\S 1316$ (Supp. I,

199. 42 U.S.C. § 1316(a) (3) (Supp. I, 1965). 
Act $^{200}$ alleging that portions of the approved state plan contravene the Constitution, the Social Security Act, or HEW regulations. The relief sought would be declaratory and injunctive. Since the Social Security Act contemplates a decision on conformity by the Secretary in the first instance, ${ }^{201}$ the injunction probably would not take the form of a direct command to stop payments to the state. Instead, the court would order him to exercise his discretion and to initiate the procedures for a review of the conformity of the plan. ${ }^{202}$ The problems inherent in such an action run the gamut of known difficulties in securing judicial review of administrative action. In this context, the major obstacles will involve the jurisdiction of the federal court, the reviewability of the Secretary's decision, and the standing of the individual welfare claimant.

\section{A. Jurisdiction}

1. Jurisdictional Statutes. As in suits against state officials under section 1983, the jurisdiction of the fecleral court must be established otherwise than by proof of the $\$ 10,000$ jurisdictional amount under section 1331.203 Aggregation of the small claims of welfare plaintiffs in a class action will probably not be permitted. ${ }^{204}$ Nor can it be successfully contended that the true amount in controversy is not the pecuniary gain of the welfare claimant but rather the full amount of federal payments to the state. Although the state's receipt of this entire sum is jeopardized by the challenge to the conformity of the state plan, the general rule has been that in suits for equitable relief the amount in controversy is measured by the possible benefit to the plaintiff and not the detriment to the defendant.205

One plausible source of federal jurisdiction is 28 U.S.C. $\S 1340$, which grants the district courts jurisdiction of cases arising under acts of Congress providing for internal revenue, without regard to amount in controversy. If

200. 5 U.S.C. $\S 1009$ (b) (1964) :

(b) The form of proceeding for judicial review shall be any special statutory review proceeding relevant to the subject matter in any court specified by statute, or, in the absence or inadequacy thereof, any applicable form of legal action (including actions for declaratory judgments or writs of prohibitory or mandatory injunction or habeas corpus) in any court of competent jurisdiction. . . . 201. 42 U.S.C. \& 1316(a) (1) (Supp. I, 1965).

202. The practical effect of such an order might well be the same as a direct order from the court as to the illegality of the Secretary's approval. Since the Secretary need not hold a hearing unless there are probable grounds for nonconformity, a direction by a court to hold such a hearing is, in effect, a finding of probable cause for nonconformity.

203. Since 28 U.S.C. \& 1343 (3) refers only to deprivations of rights under color of state law, it could not be used as a source of jurisdiction for an action against a federal adininistrator-with the possible exception of federal administrators of the District of Columbia.

204. See notes 159-65 supra and accompanying text.

205. See 1 J. Moore, Federal Practice 827 (2d ed. 1964). The problem of "inclusion," that is, what interests are to be considered in arriving at the amount in controversy, is treated in Note, Federal Jurisdictional Antount: Determination of the Matter in Controversy, 73 HARv. L. REv. 1369 (1960). It is suggested therein that courts often assert jurisdiction when no interest at issue has an obvious dollar value, if it is likely that at least one interest can legitimately be valued in excess of the minimum. Id. at 1375 . 
a statute has been upheld under the powers of Congress to tax, presumably a strong argument for jurisdiction under section 1340 can be made. When the constitutionality of the insurance tax provisions of title IX of the Social Security Act was attacked, they were upheld under the power of Congress to $\operatorname{tax}^{203}$ In the same case, however, the Supreme Court specifically avoided ruling on a challenge to the unemployment compensation provisions of title III, a program which has a structure nearly identical to that of the public assistance sections. ${ }^{207}$ Thus, it appears unlikely that section 1340 may be interpreted so broadly as to confer jurisdiction whenever a case arises under an act which merely authorizes appropriations without levying a specific tax-the Court's characterization of title III. ${ }^{208}$

Jurisdiction of some actions by welfare claimants against the Secretary may be afforded by 28 U.S.C. $\S 1361$, which gives the district courts jurisdiction of "any action in the nature of mandamus to compel ... any [federal] agency ... to perform a duty owed to the plaintiff." ${ }^{209}$ The welfare claimant's suit can be regarded as an action in the nature of mandamus if it is characterized as an attempt to compel the Secretary's exercise of his discretion to determine whether a state plan conforms to federal law. ${ }^{210}$ But the suit can alternatively be characterized as a petition to review a prior finding of conformity as an abuse of discretion, in which event section 1361 is inapplicable. Moreover, the court's jurisdiction under section 1361 depends upon the allegation of a "duty owed to the plaintiff" by the federal agency, a phrase which has been narrowly construed by the courts to exclude review of any administrative action which has involved the exercise of discretion or judgment. ${ }^{211}$

2. Jurisdiction under the Administrative Procedure Act. In view of the improbability of establishing jurisdiction under any provision of title 28 , the welfare claimant may be relegated to reliance upon section 10 of the APA itself. ${ }^{212}$ Whether this section confers jurisdiction is an open question and has been recoguized as such by the courts. ${ }^{213}$ Some of the cases which have treated section 10 as creating jurisdiction seem to have confused the concepts

206. Steward Mach. Co. v. Davis, 301 U.S. 548 (1937).

207. Id. at 598 .

208. Id.

209. This recently enacted provision was intended merely to obviate the necessity for bringing certain kinds of actions in the District of Columbia which had been the only district court to have mandamus jurisdiction. S. REP. No. 1992, 87th Cong., 2d Sess. (1962).

210 . Section 1361 was recently used to establish jurisdiction in an action to compel the Secretary of Defense to change the dishonorable nature of a servicernan's discharge. Ashe v. McNamara, 355 F.2d 277 (1st Cir. 1965). The court held that, since the serviceman had been denied counsel at his court martial, it was an abuse of the Secretary's discretion not to change the discharge classification resulting from the court martial.

211. See, e.g., Parrott v. Cary, 234 F. Supp. 572 (D. Colo. 1964); Switzerland Co. v. Udall, 225 F. Supp. 812 (W.D.N.C.), aff'd, 337 F.2d 56 (4th Cir. 1964), cert. denied, 380 U.S. 914 (1965). But see Ashe v. McNamara, 355 F.2d 277, 282 (1st Cir. 1965).

212. See notes 200-10 supra and accompanying text.

213. See, e.g., Empresa Hondurena De Vapores, S.A. v. McLeod, 300 F.2d 222, 227 n.5 (2d Cir. 1962), rev'd sib nom. McCulloch v. Sociedad Nacional de Marineros, 372 U.S. 10 (1963). 
of judicial power over the subject matter and the related but distinct issues of standing and reviewability. ${ }^{214}$ The court in Freeman v. Brown, for example, stated explicitly that "the District Court had jurisdiction to review the action of the Secretary [of Agriculture] under the Administrative Procedure Act." ${ }^{215}$ However, jurisdiction over the subject matter in that suit was clearly present-with or without the APA-for the suit arose under the Agriculture Adjustment Act, an act regulating commerce within the meaning of 28 U.S.C. $\S 1337 .{ }^{216}$ As in other decisions in which jurisdiction could have been found elsewhere, the court did not identify the other source but rather based its power to proceed squarely upon section 10 of the APA.

Other cases do not involve any readily identifiable source of jurisdiction other than the APA. ${ }^{217}$ In the recent case of Mulry v. Driver, ${ }^{218}$ the Court of Appeals for the Ninth Circuit seems squarely to have faced this issue and to liave decided that the APA confers, independent of any other statute, subject matter jurisdiction upon a federal court. The court stated that the district court slould have decided whetler the action in question was authorized by the APA, and that, if it was, "the necessary consent of the United States will be found to exist."219

Only a few cases express a contrary view. Most outspoken among these is Ove Gustavsson Contracting Co. v. Floete $e^{220}$ in which the court stated that "neither [section 10(a)] nor any otlier clause of $\$ 10$ extends the jurisdiction of the federal courts to cases not otherwise within their competence."221 However, this language does not represent a precise statement of the holding of the case: that the APA did not excuse the bringing of an action in the district court which was required by the Tucker Act ${ }^{222}$ to be brought in the Court of Claims. Indeed, as the court noted, section $10(\mathrm{c})$ of the APA itself precludes a district court from taking jurisdiction when there is an adequate

214. E.g., Shaughnessy v. Pedreiro, 349 U.S. 48 (1955); Estrada v. Ahrens, 296 F.2d 690 ( 5 th Cir. 1961). Although both courts spoke in terms of jurisdiction, the cases arose under the Immigration and Naturalization Act of 1952, which had a jurisdiction conferring section. 8 U.S.C. \$ 1329 (1964). Therefore, the issue in these cases was not whether the court had subject matter jurisdiction, but whether the particular issues involved were non-reviewable, given the court's competence, under traditional administrative law concepts. Cf. Deering Milliken, Inc. v. Johnston, 295 F.2d 856 (4th Cir. 1961). 215. 342 F.2d 205, 213 (5th Cir. 1965).

216. Mulford v. Smith, 307 U.S. 38 (1937) (holding as to 28 U.S.C. $\$ 41$ (8), now 28 U.S.C. \& 1337 (1964)).

217. McEachern v. United States, 321 F.2d 31 (4th Cir. 1963); Adams v. Witmer, 271 F.2d 29 (9th Cir. 1959).

218. 366 F.2d 544 (9th Cir. 1966).

219. Id. at 547.

220. 278 F.2d 912 (2d Cir.), cert. denied, 364 U.S. 894 (1960).

221. Id. at 914. See also Kansas City Power \& Light Co. v. McKay, 225 F.2d 924 (D.C. Cir.), cert. dentied, 350 U.S. 884 (1955). In Kansas City, the court observed, in dictum, that $\S 10(\mathrm{~b})$ did not confer upon the courts jurisdiction "over an action not otherwise cognizable by them." 225 F.2d at 933 .

222. 28 U.S.C. \& 1491 (1964). The provision has since been amended [see Supp. I, 1965], but the court in Ove was dealing with the earlier section which providcd exclusive relief in the Court of Claims for contract actions against the United States for over $\$ 10,000$. 
remedy available in another court. ${ }^{223}$ The significance of the court's dictum concerning the APA is reduced as well by the court's alternative holding that the plaintiff had failed to exhaust his administrative remedies under the disputes clause of the government contract.224

There are persuasive policy reasons for regarding section 10 as conferring federal judicial jurisdiction. As Professor Jaffe has argued:

Cases have arisen where the sole basis of jurisdiction (other than the APA) would appear to be the "federal question" jurisdiction which requires a jurisdictional amount. It does seem inapt to make it a condition of a suit against an officer that the right asserted be given a value, if indeed in many cases it is even possible. This being so it would seem sound to treat $\S 10$ as a source of jurisdiction with respect to any of the questions which that section makes reviewable, and some courts have so held.25

The welfare claimant's suit falls precisely within this category of cases. Most often it will be practically impossible to evaluate the plaintiff's interest, particularly when the challenge is to an invalid condition upon the receipt of aid which has not yet been cut off. Even if the claimant's pecuniary loss is determined to be less than $\$ 10,000$, the exercise of federal judicial power should not thereby be precluded. At stake is the very livelihood and perhaps survival of the plaintiff. In such circumstances it is indeed "inapt" to require an amount in controversy which-because it is virtually unattainable by welfare claimants-would effectively insulate the Secretary's determinations from judicial oversight.

\section{B. Reviewability}

Section 10 (c) of the Administrative Procedure Act provides for judicial review of any final agency action "except so far as (1) statutes preclude judicial review or (2) agency action is by law committed to agency discretion. . . ."226

1. Statutory Preclusion. No section of the Social Security Act explicitly precludes judicial review of the Secretary's approval of a state welfare plan. The act does, however, specifically provide for review of the administrator's decisions under the federal social security insurance program ${ }^{227}$ and of the Secretary's finding of non-conformity of a state plan. ${ }^{228}$ It may be argued that these provisions for the review of certain administrative decisions evince an intent to limit judicial inquiry to the actions covered by those sections.

223. Section 10(c) of the APA reads: "Reviewable Acts-Every agency action made reviewable by statute and every final agency action for which there is no other adequate remedy in any court shall be subject to judicial review ...." 5 U.S.C. § 1009 (c) (1964) (emphasis added).

224. 278 F.2d at 915.

225. L. Jaffe, Judiclal Control of Administrative Action 165 (1965).

226. 5 U.S.C. \& 1009 (c) (1964).

227. 42 U.S.C. $\$ 405(\mathrm{~g})(1964)$.

228. 42 U.S.C. \$ 1316 (a) (3) (Supp. I, 1965). 
The Supreme Court has employed reasoning of this sort in construing another, unrelated statute in Sreitchmen's Union v. National Mediation Board:

When Congress ... provided for judicial review of two types of orders or awards and in ... the same Act omitted any such provision as respects a third type, it drew a plain line of distinction. ${ }^{220}$

However, the Switchmen's Union case cannot support general application of an expressio unius analysis in this context. The Court's statement was merely advanced to reinforce the conclusion that the legislative history showed a congressional intent to prevent judicial interference. ${ }^{230}$ In this respect the Social Security Act is clearly distinguishable, for there is no indication that Congress intended to preclude review or even contemplated that such review might be sought by welfare claimants. ${ }^{231}$ Nor is the provision for review of individual complaints in the insurance program particularly persuasive under the Switchmen's language. Indeed, this program-which is administered directly by the federal government and is independent of any state participation-should realistically be viewed as a separate act for these purposes; there is evidence that Congress' primary concern in establishing judicial review was to forestall anticipated constitutional objections to the insurance section of the statute. Finally, the approach taken by the Supreme Court in Switchmen's Union has been severely criticized and rarely followed. ${ }^{232}$ The more logical view, and one more consistent with the broad policy of the Administrative Procedure Act is that " $[t]$ he right to judicial review is a basic protection. It is not too great a burden upon Congress to require it to speak to the issue."233

Despite these criticisms, such expressio unius reasoning persists: its most recent reaffirmation may be found in Paducah Junior College v. Secretary of Health, Education and Welfare. ${ }^{234}$ Pursuant to a state plan which had been approved by $\mathrm{HEW}$, the plaintiff sought and was denied a federal grant under the Higher Education Facilities Act of 1963. The district court dismissed the suit, holding that Congress had precluded judicial review of such decisions

229. 320 U.S. 297, 306 (1943).

230. Id. at 302-03, 305 .

231. The legislative history of the Social Security Act casts some light on the failure to provide for review. In many respects welfare was viewed as an interim measure in which federal participation would become unnecessary upon a resumption of normal economic conditions: "Many of the children included in relief families present no other problem than that of providing work for the breadwinner of the family." S. REP. No. 628, 74th Cong., 1st Sess. 17 (1935).

232. See L. JafFe, supra note 225, at 357. See also $4 \mathrm{~K}$. Davis, Administrative Law Treatise $\$ 28.09$, at $42-44$ (1958). Compare $\mathrm{R}$. Berger, Administrative Arbitrariness and Judicial Review, 65 CoLUM. L. REv. 55 (1965) (advocating a significant broadening of judicial review for abuse of discretion), with $4 \mathrm{~K}$. DAV1S, ADAIINISTRATIVE LAW TREATISE (Supp. 1965, at 15-30). On the Switchmen's Union case itself, see H. HART \& H. Wechsler, The Federal Courts and the Federal System 327 (1953).

233. L. J AFFE, supra note 225 , at 373 .

234. 255 F. Supp. 147 (W.D. Ky. 1966). 
by the Commissioner of Education. The court found it particularly significant ${ }^{235}$ that the act specifically provided for review in two instances-when the Commissioner disapproved a state plan and when a federal loan was denied to an individual institution - but was silent as to review of the agency's refusal of grants. In view of the close parallels between the facts of Paducah and those generally involved in welfare claims, the decision, if followed, would appear to constitute a considerable barrier to judicial review of the Secretary's determinations as to the conformity of state welfare programs. However, the decision contradicts the weight of reasoned commentary in the area and should succumb to persuasive arguments founded on the policy of the APA and the pressing need for judicial surveillance of the administration of the Social Security Act.

2. Committed by Law to Agency Discretion. The APA precludes judicial review of agency action which is "by law committed to agency discretion." ${ }^{236}$ The Social Security Act does, of course, confer extensive discretion upon the Secretary with regard to state welfare plans. He is empowered to judge, in the first instance, whether a hearing is necessary and whether the state plan does comply with the statute. ${ }^{237}$ The proper interpretation of the discretionary exception in section 10 has been the subject of considerable debate. ${ }^{238}$ Opinion is unanimous, however, that not every case in which some discretion is granted to the administrator is excluded by this provision. The courts have recognized that there is a degree of discretion in every agency action. ${ }^{239}$

A useful distinction which has emerged in applying section 10 focuses upon whether the statute under consideration characterizes the agency action as permissive or mandatory. ${ }^{240}$ Thus, in Freeman v. Brown, ${ }^{241}$ the APA was held to authorize review of a decision by the Secretary of Agriculture concerning a classification of tobacco under the price support program. The court concluded that the Secretary's wide discretion in making such classifications was not unlimited and that judicial supervision was proper to compel him to apply compulsory statutory criteria in his decisions. Similarly, the requirements of the Social Security Act-to which state plans must conform before

235. See id. at 150 .

236. 5 U.S.C. \& 1009 (c) (1964).

237. 42 U.S.C. \& 1316 (Supp. I, 1965). If the Secretary rules that the state plan does not conform, the state may petition for a hearing which the Secretary must grant.

238. Compare R. Berger, supra note 232 , with $4 \mathrm{~K}$. Davis, Administratrve Law Treatise $\$ 28.16$ (Supp. 1965).

239. See, e.g., Homovich v. Chapman, 191 F.2d 761, 764 (D.C. Cir. 1951).

240. See, e.g., Freeman v. Brown, 342 F.2d 205, 212 (5th Cir. 1965). Of course, in a larger context, the most important factors affecting reviewability will be the nature of the injury done by the allegedly unlawful act of the agency. In this respect, as suggested by Professor Davis, the scale runs from agency action which imposes definite obligations to agency action which merely fails to give benefits. See $4 \mathrm{~K}$. Davis, Administrative LAW TREATISE $\$ 28.19$, at 103 (1958).

241. 342 F.2d 205, 212-13 (5th Cir. 1965). 
they are approved-are mandatory, and the Secretary is specifically commanded to exact compliance with these criteria. ${ }^{242}$ To this extent, then, his otherwise broad discretion is strictly curtailed.

The proper judicial attitude to reviewability should he that administrative deviation from clear statutory limitations is an abuse of discretion which will be subject to review unless there are countervailing social policies which dictate against judicial supervision of the regulatory scheme. ${ }^{243}$ No such overriding policy would insulate the Secretary of Health, Education, and Welfare from judicial review of his conformity findings. On the contrary, review is necessary to assure the eradication of state practices which infringe upon the Constitution or federal statutes-though they have escaped the Secretary's attention.

\section{Standing}

A denial of standing to welfare claimants would render the Secretary's finding in favor of a state plan effectively unreviewable, for no other party would seek to challenge the determination. ${ }^{244}$ Indeed, if the problems of jurisdiction and specific exclusion under section 10 are surpassed, reviewability depends solely upon the standing of the plaintiff. Section 10(a) of the APA reads :

Right of review-Any person suffering legal wrong because of any agency action, or adversely affected or aggrieved by such action within the meaning of any relevant statute, shall be entitled to judicial review thereof. ${ }^{245}$

It has been argued that the legislative history of this section warrants a broad reading which would give standing to anyone actually injured by administrative action covered by the APA - that only the word "aggrieved" and not the phrase "adversely affected" is modified by "within the meaning of any relevant statute." ${ }^{246}$ However, most courts have rejected this construction and have held that, in the absence of a "relevant statute," the plaintiff's standing

242. 42 U.S.C. $\S \S 304,604,1204,1354$ (1964).

243. It may be argued that at least part of the difficulty of the discretion problem would be removed by looking behind the statutory language or rigid classification of the nature of the claim against the administrator to the reason for the granting of whatever degree of discretion is present. When the rationale for discretion is that the matters involved are peculiarly outside of the sphere of judicial competence or are matters of internal administration of government, the discretion should be accepted as final. See Duba v. Schuetzle, 303 F.2d 570 (8th Cir. 1962). When, however, the interest of the government is not exclusive and when the application of other established doctrines which would cause the judicial branch to refrain from interfering is improper, the violation of the bounds of administrative discretion in the form of the violation of statutory standards for the exercise of discretion should be reviewable.

244. "For instance, when the party who challenges adninistrative action has better standing than any other party, a holding that the challenging party lacks standing is the equivalent of a holding of unreviewability. .." $3 \mathrm{~K}$. DAvis, Administrative LAW TREATISE $\$ 22.01$, at 208 (1958).

245. 5 U.S.C. \& 1009 (a) (1964).

246. $3 \mathrm{~K}$. Davis, Administrative Law Treatise $\$ 22.02$, at 211-13 (1958). 
must be tested by the "legal wrong" criterion. ${ }^{247}$ Since no "person aggrieved" statute applies to the welfare claimant, his recourse to a federal court for review of the Secretary's decision will hinge upon the meaning of this standard.

1. Legal Wrongs and Legal Rights. Use of the phrase "legal wrong" in section 10 incorporated the prior, non-statutory law of standing. The leading explication of this body of law was the Supreme Court decision in Perkins v. Lukens Steel Co. ${ }^{248}$ In that case, the Court denied steel producers who sought to contract with the federal government standing to challenge the validity of the Secretary of Labor's interpretation of the Public Contracts Act of 1936.249 Standing derives only from governmental action which threatens or invades a recognized legal right of the plaintiff; mere economic loss cannot be the source of such rights. Thus, the steel producers lacked standing, for they had no independent right to contract with the Government. Nor did any legal rights vest in the plaintiffs by virtue of the statutory requirement that the Secretary follow certain procedures and apply specified criteria in contracting with private citizens. These restrictions were not for the protection of the plaintiffs, and, in any event, they were merely non-binding, "self-imposed restraints" on the Government. ${ }^{250}$ The welfare claimant does not have an absolute right to public assistance. But he does assert a right to have the state consider his claim in accordance with constitutional and statutory imperatives - a right which is clearly threatened or invaded by the Secretary of Health, Education, and Welfare when he approves a state plan which does not ensure such compliance. Nevertheless, Perkins implies that private rights of this nature cannot accrue from the Government's "selfimposed restraints" on the distribution of benefits. Subsequent cases have, however, modified this aspect of the Perkins decision. In Gonzalez v. Freeman, ${ }^{251}$ for example, the Court of Appeals for the D.C. Circuit held thatwhile there may be no right to contract with the Government-there is a "right" to require that administrative officials respect congressionally established procedures in determining whether or not, and to whom, contracts should be given. Although Perkins was distinguished on the grounds that the plaintiff in Gonzalez had been cut off from an already existing contract, ${ }^{252}$ the decision represents a substantial and sound qualification of the earlier decision in Perkins.

Perkins rested upon a judicial perspective which has been, in great measure, altered in recent years. The emphasis of the opinion was upon the in-

247. See, e.g., Paducah Junior College v. Secretary of Health, Educ. \& Welfare, 255 F. Supp. 147, 150 (W.D. Ky. 1966) (dictum).

248. 310 U.S. 113 (1940).

249. 41 U.S.C. $\$ \S 35-45$ (1964).

250. 310 U.S. at 127.

251. 334 F.2d 570, $574-75$ (D.C. Cir. 1964).

252. See id. at 574 . 
appropriateness of judicial interference with the type of administrative action involved-the making of public contracts. Several spheres of government activity have traditionally been viewed as areas in which judicial review should be precluded or severely limited. ${ }^{253}$ In some areas-foreign affairs ${ }^{254}$ and military matters, ${ }^{255}$ for example-the reluctance persists today. But the broad category of "bounties and privileges"-including government contracts -which was often considered entitled to this "hands-off" treatment, no longer retains its immunity from judicial review. ${ }^{250}$ As the governmentally created "privileges" have become increasingly numerous and important ${ }^{257}$ the rationale underlying such insulation has become the subject of sharp criticism. Particularly in view of section 10 of the Administrative Procedure Act the general presumption against review of government action concerning "privileges" can no longer be supported. ${ }^{258}$

2. Legislative Intent to Protect-An Emerging Criterion for Standing. The public assistance provisions of the Social Security Act bear strong likenesses to a number of other social welfare programs-including Urban Renewal, ${ }^{269}$ "Medicaid," ${ }^{260}$ Federal Aid to Education, ${ }^{201}$ and Public Housing. ${ }^{202}$ These statutes have parallel forms of administration: a federal agency is charged with distributing funds or other aid to state, local, or duly authorized private bodies, and these non-federal bodies determine the specific allocation of the funds, subject to broad conditions imposed by the federal statute and enforced by the federal administrator. Cases arising under these programs have raised the question whether an individual who is injured by the local agency's non-compliance with federal standards may obtain judicial review of the federal administrator's failure to enforce these standards. Although the courts have yet to recognize that there are problems of standing peculiar to this situation, some of the cases reveal a trend away from strict adherence to the recognized "legal right" language of Perkins and toward the formulation of a new test: whether the federal requirement violated by the state was one which Congress imposed to benefit or protect a class of which the plaintiff is a member.

The Court of Appeals for the Second Circuit has been the leader in this

253. See L. JAFFE, supra note 225 , at $363-71$.

254. See Pauling v. McNamara, 331 F.2d 796 (D.C. Cir. 1963), cert. denied, 377 U.S. 933 (1964).

255. See Orloff v. Willoughby, 345 U.S. 83, 93-94 (1953). But see Harmon v. Brucker, 355 U.S. 579 (1958).

256. See, e.g., Freeman v. Brown, 342 F.2d 205 (5th Cir. 1965). The whole nature of what constitutes a "privilege" is subject to considerable change today. Sec, e.g., D. Westfall, Agricultural Allotments as Property, 79 HARv. L. Rev. 1180 (1966).

257. See, e.g., Economic Opportunity Act of 1964, 42 U.S.C. $\$ \$ 2701-2981$ (1964), as amended (Supp. I, 1965).

258. See L. JAFFE, supra note 225 , at 369 .

259. See 42 U.S.C. \$\$ 1441, 1451 (1964).

260. See 42 U.S.C. $\$ \$ 1396-1396 d$ (Supp. I, 1965).

261. See 20 U.S.C. $\$ \$ 236-44$ (1964), as amended (Supp. I, 1965).

262. See 42 U.S.C. $\$ \$ 1401,1410-11$ (1964), as amended (Supp. I, 1965). 
development. In the area of public housing the court unequivocally equated the violation of a statutory provision intended to protect the plaintiffs' class with the existence of a "legal wrong" under the APA. Thus, in Shanks Village Committee v. Cary, ${ }^{203} 340$ tenants brought suit against the Public Housing Administrator to enjoin enforcement of a $15 \%$ rent increase, seeking an order to compel him to comply with the requirement of the Lanham Act that rents be within the financial reach of servicemen with families. ${ }^{204}$ The court's finding of standing was based upon the "right" of the veterans not to be evicted from their apartments by the unlawful conduct of the federal administrator.

While the Shanks case may be distinguished from that of the welfare claimant in that the plaintiffs were directly injured by acts of the federal administrator without the intervention of a state agency, the Second Circuit's urban renewal decisions, which evince a similar emphasis on legislative intent, cannot be distinguished on that ground. In Gart v. Cole, ${ }^{265}$ residents of the proposed Lincoln Center renewal site sued for injunctive relief against the HHFA alleging infractions of the bidding procedures set forth in the federal act, and a failure to comply with the statutory requirement of a public hearing to challenge the city relocation plan. The court held that the plaintiffs did have standing under the APA to challenge the failure to accord a hearing, ${ }^{206}$ for that statutory procedure clearly was inserted for their benefit. But it ruled that they could not challenge the bidding irregularities, since "these sections seem designed to protect not the interests of landowners or tenants in a redevelopment area, but those of the public at large."267

Similar reasoning, focusing upon the existence of a congressional intent to protect the plaintiffs, is found in Berry v. HHFA. ${ }^{288}$ In that case, hotel owners sought to challenge an urban renewal project which provided for the construction of transient housing units which would compete with the plaintiffs' business. They invoked a statutory command that no project include such provisions unless the available transient housing in the community has been surveyed and found inadequate. The court denied standing. Although Perkins was cited, the decision rested primarily on the ground that the statutory criterion was established not to protect the hotel owners but, rather, to preserve the residential character of renewal projects and to ensure that the limited federal funds are not wasted on unnecessary commercial hotels.

While courts other than the Second Circuit have occasionally indicated that a congressional intent to protect the interests asserted by appellants will confer standing upon them, ${ }^{269}$ most have failed to recognize its relevance to

263. 197 F.2d 212 (2d Cir. 1952).

264. 42 U.S.C. \& 1571 (1964).

265. 263 F.2d 244 (2d Cir.), cert. denied, 359 U.S. 978 (1959).

266. Id. at 250 .

267. Id.

268. 340 F.2d 939 (2d Cir. 1965).

269. See, e.g., Merge v. Sharott, 341 F.2d 989 (3d Cir. 1965). 
standing under the "legal wrong" standard of the Administrative Procedure Act..270 The àproach of the Second Circuit, however, is sound and should be extended. If those persons whom the statute and Constitution intended to protect cannot challenge its violation, the administrative abuse is effectively unreviewable. ${ }^{271}$ In Perkins itself the Supreme Court supported its holding with the observation that Congress had not designated the disputed statutory provision for the benefit of the plaintiffs. Moreover, in cases arising under "persons aggrieved" statutes, the tendency has been to broaden the scope of standing to include persons whose interests were intended to be served by the statute and who have actually been injured by the action of the agency. Thus, whereas courts traditionally denied standing unless economic injurysuch as that of a competitor-could be shown, ${ }^{272}$ more recent cases have granted standing to consumers, television audiences, and residents whose interests were the raison d'être of the regulatory agency. ${ }^{273}$ Underlying this trend is a growing recognition that, although agencies are created to protect the public interest, they have not always done so, and their performance in this regard would be aided by according some role in the administrative process to responsible organs of public expression. ${ }^{274}$ This lesson is fully applicable to the administration of welfare; experience has shown that the Secretary of Health, Education, and Welfare has not been able to prevent infringement of the rights of individuals by state welfare programs.

Application of the "intent to protect" test to welfare proceedings should result in the finding of standing in nearly all cases. Most suits by welfare claimants will be based upon alleged violations of constitutional rights. Since the Bill of Rights was certainly intended to protect the interests of individuals,

270. See, e.g., Rural Electrification Administration v. Central La. Elec. Co., 354 F.2d 859 (5th Cir.), cert. denied, 87 S. Ct. 34 (1966). In that case, standing was denied to a public utility to enjoin a loan by the REA to a competing co-op on a clain of violation of a statute in making the loan. The violation was of a provision providing that no loans should be made where there are already existing adequate central power provisions. Accord, Johnson v. Redevelopment Agency, 317 F.2d 872 (9th Cir.), cert. denicd, 375 U.S. 915 (1963) ; Harrison-Halsted Community Group, Inc. v. HHFA, 310 F.2d 99 (7th Cir. 1962), cert. denied, 373 U.S. 914 (1963); Caulfield v. United States Dep't of Agriculture, 293 F.2d 217 (5th Cir. 1961), cert. dismissed, 369 U.S. 858 (1962); Paducah Junior College v. Secretary of Health, Educ. \& Welfare, 255 F. Supp. 147 (W.D. Ky. 1966).

271. See note 244 supra.

272. FCC v. Sanders Brothers Radio Station, 309 U.S. 470 (1940).

273. See, e.g., Office of Communication of the United Church of Christ v. FCC, 359 F.2d 994, 1000-06 (D.C. Cir. 1966) ; Scenic Hudson Preservation Conference v. FPC, 354 F.2d 608, 615-17 (2d Cir. 1965), cert. denied, 384 U.S. 941 (1966). In the former case, standing was granted to responsible groups representing Negro television viewers in the Jackson, Mississippi area to challenge the conditional grant of a license to a station which had been, allegedly, racist in its policies. For treatment of the general problem of standing to viewers, consumers, etc., see Comment, Standing of Television Vicucrs to Contest FCC Orders: The Private Action Goes Public, 66 Cozum. L. REv. 1511, 1512-20 (1966).

274 . "Nor does the fact that the Commission itself is directed by Congress to protect the public interest constitute adequate reason to preclude the listening public from assisting in that task." Office of Communication of the United Church of Christ v. FCC, 359 F.2d 994, 1003 (D.C. Cir. 1966). 
claimants should be accorded standing in these cases. Moreover, most of the statutory provisions which welfare claimants allege have been violated are designed to protect the individual claimant. Although the act vests considerable discretion in the states, ${ }^{275}$ the restrictions which it does impose were meant to bind; the legislative history is unambiguous that both the states and the Secretary were to treat them as absolutely mandatory: "These conditions are entirely appropriate and are, in fact, essential if the Federal Government is to bear a part of the burden."276 That these mandatory conditions upon the states' receipt of federal aid are intended to protect needy individuals is equally clear from the legislative history. "[These conditions] do not involve dictation by the Federal Government, but only establish standards which will make it reasonably certain that the States are honestly trying to meet the problem of the [welfare recipient]."277 Indeed, the reports are replete with evidence of congressional concern for the plight of needy individuals. ${ }^{278}$ Even where the legislative history is silent or inconclusive with respect to the purpose of a particular statutory provision, the intent to protect individual claimants will usually be clear on its face. Requirements such as a fair hearing, or the distribution of welfare information, are unquestionably imposed for the individual's benefit. Others, like the criteria governing the selection and tenure of administrative personnel, are clearly unrelated to the direct interests of the welfare recipient, but infractions of such requirements are not likely to be challenged in court. Finally, the purpose of some provisions may be ambiguous. For example, the act's insistence upon the uniform application of plans throughout the state may reflect a congressional attempt to alleviate the administrative burden of the Secretary, or it may be designed as a safeguard against local discrimination; in the absence of definitive legislative history neither interpretation can be entirely discounted. Where the legislative purpose underlying the provision cannot be discovered, or where the requirement was intended to serve a dual function, the fact that a fundamental right of the individual is secured by its operation should be deemed sufficient to give him judicial standing to ensure that it is enforced.

275. See note 22 supra and accompanying text.

276. S. Rep. No. 628, 74th Cong., 1st Sess. 4 (1935).

277. Id. at 6 . Actually, this statement was made with reference to the dependent aged rather than the AFDC recipient. Indeed, most of the legislative history related primarily to title II of the original bill, providing for a social security insurance system. See E. Witte, The Development of THe Sociar. Security Act 93, 102-04 (1962). In the area of public assistance, attention was focused on title I, providing for old-age assistance, and its relation to title II in the context of a long-range program. See G. Ste1ner, Soctat. Insecurity: The Politics of Welfare 18-47 (1966); E. Witte, supra at 78-79. Nevertheless, since the structure of both the AFDC and the AB sections were closely analogous to that of the OAA title, much of the history of title I is applicable to these titles as well. The reports themselves are explicit about the interrelationship: "These grants-in-aid are made under conditions very similar to the grants for old-age assistance." S. REP. No. 628, 74th Cong., 1st Sess. 19 (1935).

278. See H. REp. No. 615, 74th Cong., 1st Sess. 3-6, 10 (1935) ; S. Rer. No. 628, 74th Cong., 1st Sess. 16-19, 22 (1935). 